Studia nad Autorytaryzmem i Totalitaryzmem 42, nr 4

Wrocław 2020

https://doi.org/10.19195/2300-7249.42.4.9

MAŁGORZATA MASTERNAK-KUBIAK

ORCID: 0000-0002-0395-3128

Uniwersytet Wrocławski

małgorzata.masternak-kubiak@uwr.edu.pl

JACEK PRZYGODZKI

ORCID: 0000-0003-2459-933X

Uniwersytet Wrocławski

jacek.przygodzki@uwr.edu.pl

\title{
Status kombatanta z tytułu uczestnictwa w Istriebitielnych Batalionach (rozważania historycznoprawne i dogmatycznoprawne)
}

\begin{abstract}
Abstrakt: Artykuł został poświęcony ukazaniu genezy powstania i działalności tak zwanych Istriebitielnych Batalionów (IB) - batalionów niszczycielskich funkcjonujących na terenach Wołynia i Galicji Wschodniej — formacji militarnych, które jako służba pomocnicza Armii Czerwonej, często dowodzona przez oficerów totalitarnej formacji NKWD, walczyły z oddziałami Organizacji Ukraińskich Nacjonalistów (OUN), frakcja Bandery oraz Ukraińskiej Powstańczej Armii.

Główny ideolog OUN Dymytro Doncow był zafascynowany ideologią faszystowską rozwijającą się w Europie, dlatego też — idąc za swoim ideologiem oraz wraz ze swoim rozwojem — OUN i jej największa grupa: frakcja Bandery (OUN-B) przybrały charakter faszystowski. Również kierownik referatu wojskowego OUN Mychajło Kołodzinśkyj, po opuszczeniu więzienia w II Rzeczypospolitej, został wysłany przez OUN do faszystowskich Włoch, gdzie Benito Mussolini wyraził zgodę na utworzenie obozów szkoleniowych dla nacjonalistów ukraińskich, jak również dla chorwackich ustaszy. Tam tworząc ukraińską doktrynę wojenną, zapowiadał krwawą rozprawę z Polakami, Żydami i Rosjanami. Te zapowiedzi spełniły się w czasie II wojny światowej, a tragiczne wydarzenia na Wołyniu i Galicji Wschodniej opisane w niniejszym artykule ewidentnie wyczerpują znamiona lemkinowskiej definicji genocydu, która znalazła się w Konwencji o zapobieganiu i karaniu zbrodni ludobójstwa przyjętej przez Zgromadzenie Ogólne ONZ 9 grudnia 1948 roku.

W tekście nie zostanie poruszona kwestia działalności Istriebitielnych Batalionów na terenie Litwy i Białorusi, gdyż ich działalność była zgoła odmienna. Nie broniły one tam zazwyczaj ludności polskiej, a zwrócone były głównie przeciwko podziemiu niepodległościowemu, wspomagając totalitarną NKWD.
\end{abstract}


Druga część opracowania to dogmatycznoprawna analiza orzecznictwa sądów polskich w sprawie przyznawania osobom służącym w opisywanej formacji statusu kombatantów. Zgodnie z obowiązującym prawem uczestniczenie obywateli polskich w Istriebitielnych Batalionach na dawnych ziemiach polskich w województwach lwowskim, stanisławowskim, tarnopolskim i wołyńskim w latach 1944-1945 w obronie ludności polskiej przed ukraińskimi nacjonalistami stanowi działalność kombatancką. Jednak po 1989 roku nie było to takie oczywiste. Kierownik Urzędu do spraw Kombatantów stał konsekwentnie na stanowisku, że uprawnienia kombatanckie nie przysługują z mocy art. 21 ust. 2 pkt 3 ustawy o kombatantach osobie, która służyła w totalitarnych formacjach NKWD albo w innych organach represji ZSRR, działających przeciwko narodowi i państwu polskiemu. W orzecznictwie Naczelnego Sądu Administracyjnego istniała też duża rozbieżność w kwestii stosowania przepisów ustawy o kombatantach w odniesieniu do uczestnictwa w walkach w ramach Istriebitielnych Batalionów. Dlatego też, ze względu na złożoność problemu, wydaje się jak najbardziej zasadne prześledzenie tej procedury z punktu widzenia historycznego i jurydycznego.

Słowa kluczowe: Istriebitielne Bataliony, UPA, OUN-B, Samoobrona, AK, Wołyń, Galicja Wschodnia, ludobójstwo, kombatanci, Naczelny Sąd Administracyjny, Wojewódzki Sąd Administracyjny, Trybunał Konstytucyjny.

\title{
STATUS OF A WAR VETERAN DUE TO PARTICIPATION IN THE ISTRIEBITIELNE BATTALIONS (CONSIDERATIONS FROM THE PERSPECTIVE OF LEGAL HISTORY AND LEGAL DOGMATICS)
}

\begin{abstract}
The article is devoted to showing the origin and operations of the so-called Istriebitielne Battalions (IB): destruction battalions which functioned as military formations in the territory of Volhynia and Eastern Galicia, and as an auxiliary service of the Red Army - often commanded by officers of the totalitarian NKVD - fought against units of the Organization of Ukrainian Nationalists - Bandera faction and the Ukrainian Insurgent Army.

The main ideologist of the OUN, Dmytro Dontsov, was fascinated by the fascist ideology emerging in Europe, thus following his ideologist and with its development the OUN and its largest group - Bandera's faction (OUN-B) evolved into a fascist one. The head of the OUN military department, Mychajło Kołodzinśkyj, after leaving prison in the Second Polish Republic, was also sent by the OUN to fascist Italy, where Benito Mussolini agreed to set up training camps for Ukrainian nationalists as well as for the Croatian Ustasha. There, creating a Ukrainian war doctrine, he predicted a bloody crackdown against Poles, Jews, and Russians. These predictions came true during the Second World War, and the tragic events in Volhynia and Eastern Galicia described in the article meet the Lemkinian definition of genocide as found in the Convention on the Prevention and Punishment of the Crime of Genocide adopted by the UN General Assembly on 9 December 1948.

The article will not discuss the activities of the Istriebitielne Battalions in Lithuania and Belarus, because their operations were fundamentally different. They did not usually defend the Polish population, but were directed mainly against the pro-independence underground, assisting the totalitarian NKVD.

The second part of the paper is an analysis from the perspective of legal dogmatics of the Polish courts' jurisprudence in the matter of granting war veteran status to people who served in the described formation. According to the current law, the participation of Polish citizens in the Istriebitielne Battalions, in the former Polish territories of the voivodeships of Lviv, Stanislaw, Tarnopol, and Volhynia in the years 1944-1945, in defence of the Polish population against Ukrainian nationalists, constitutes veteran activity. However, after the year 1989 this was not so obvious. The Head of the Office for War
\end{abstract}


Veterans consistently took the position that under art. 21 (2)-(3) of the Law on War Veterans, a person who served in totalitarian NKVD formations or other repressive organs of the USSR, acting against the Polish Nation and State, is not entitled to war veteran privileges. In the jurisprudence of the Supreme Administrative Court, there was also a large discrepancy in the applicability of the Law on War Veterans provisions concerning participation in combat as a part of the Istriebitielne Battalions. Therefore, due to the complexity of the problem, it seems most justified to analyse this procedure from a historical and jurisprudential point of view.

Keywords: Istriebitielne Battalions, UPA, OUN-B, self-defence, Home Army, Volhynia, Eastern Galicia, genocide, war veterans, Supreme Administrative Court, Provincial Administrative Court, Constitutional Tribunal.

II wojna światowa była okresem niebywałych zbrodni popełnianych nie tylko na jej frontach, ale również na terenach okupowanych przez uczestników działań zbrojnych. Właśnie okropieństwa wojenne pobudziły różne narodowości do wystąpień przeciwko swoim sąsiadom, ludziom, z którymi współżyli w zgodzie przez całe pokolenia. Z perspektywy czasu okropności wojny i bestialskie zachowania ludzi w trakcie jej trwania wydają się nieprawdopodobne, jednak dokumenty i wspomnienia ocalałych dają obraz tamtych czasów.

Celem opracowania jest przedstawienie genezy powstania i działalności tak zwanych Istriebitielnych Batalionów ${ }^{1}$ (IB) - batalionów niszczycielskich funkcjonujących na terenach Wołynia i Galicji Wschodniej - formacji militarnych, które jako służba pomocnicza Armii Czerwonej walczyły z oddziałami nacjonalistów ukraińskich, często dowodzone przez oficerów totalitarnej formacji NKWD. W artykule nie zostanie poruszona kwestia działalności IB na terenie Litwy i Białorusi, gdyż ich działalność była tam zgoła odmienna. Nie broniły one tam zazwyczaj ludności polskiej, a zwrócone były głównie przeciwko podziemiu niepodległościowemu.

Druga część opracowania to dogmatycznoprawna analiza orzecznictwa sądów polskich w sprawie przyznawania osobom służącym w opisywanej formacji statusu kombatantów. Zgodnie z obowiązującym prawem uczestniczenie obywateli polskich w Istriebitielnych Batalionach na dawnych ziemiach polskich w województwach lwowskim, stanisławowskim, tarnopolskim i wołyńskim w latach 1944-1945 w obronie ludności polskiej przed ukraińskimi nacjonalistami stanowi działalność kombatancką. Jednak po 1989 roku nie było to takie oczywiste. Kierownik Urzędu do spraw Kombatantów stał konsekwentnie na stanowisku, że uprawnienia kombatanckie nie przysługują z mocy art. 21 ust. 2 pkt 3 ustawy

${ }^{1}$ Nazwa formacji pochodzi od rosyjskiego czasownika istriebit, oznaczającego „zniszczyć całkowicie". Tłumaczy się ją jako bataliony niszczycielskie, pościgowe, szturmowe lub likwidacyjne. W polskim prawodawstwie używa się wobec tej formacji także określeń „niszczycielskie bataliony”, „bataliony szturmowe”. 
o kombatantach osobie, która służyła w totalitarnych formacjach NKWD albo w innych organach represji ZSRR, działających przeciwko narodowi i państwu polskiemu. W orzecznictwie Naczelnego Sądu Administracyjnego istniała też duża rozbieżność w kwestii stosowania przepisów ustawy o kombatantach w odniesieniu do uczestnictwa w walkach w ramach Istriebitielnych Batalionów. Dlatego też, ze względu na złożoność problemu, wydaje się jak najbardziej zasadne prześledzenie tej procedury z punktu widzenia historycznego i jurydycznego.

Polski prawnik Rafał Lemkin, doradca głównego oskarżyciela amerykańskiego w Trybunale Norymberskim R.H. Jacksona, jeszcze w trakcie II wojny światowej w swoim dziele Axis Rule in Occupied Europe: Laws of OccupationAnalysis of Goverment - Proposals for Redress stworzył pojęcie genocide. Było to połączenie greckiego słowa genos ('rasa, szczep, klan') i łacińskiego cide ('zabijanie'). W języku polskim przyjęto tłumaczenie „ludobójstwo”, a zostało ono po raz pierwszy użyte w czasie procesu gauleitera Kraju Warty Arthura Greisera w czerwcu 1946 roku. Według Lemkina genocyd może przejawiać się nie tylko w działaniu zmierzającym do fizycznego wyniszczenia określonej grupy, ale również w zabiegach politycznych, prawnych, ekonomicznych i społecznych ${ }^{2}$.

Ludobójstwo według wskazanego badacza dokonywane jest $\mathrm{w}$ dwóch fazach. Pierwsza polega na zniszczeniu podstaw narodowych danej grupy czy narodu, podczas gdy druga charakteryzowała się narzuceniem zasad narodowych najeźdźcy tej ludności, której pozwolono pozostać na dotychczasowym terenie zamieszkania, albo własnym obywatelom zasiedlającym teren wysiedlonej rdzennej ludności. Genocyd był konglomeratem działań ukierunkowanych na zniszczenie określonej grupy, a poszczególne jego elementy dotykały jednostki, postrzeganej przez pryzmat bycia członkiem tej grupy, dlatego Lemkin wyróżnił kilka technik ludobójstwa. Były to działania na płaszczyźnie politycznej, społecznej, biologicznej, kulturowej, ekonomicznej, fizycznej, moralnej oraz religijnej i nie zawsze musiały się wiązać z masowymi mordami. Zawsze jednak motywem działania musiała być chęć zniszczenia grupy jako całości ${ }^{3}$.

Koncepcja genocydu Lemkina, mimo że nie występowała w karcie Międzynarodowego Trybunału Wojskowego, na podstawie którego sądzono zbrodniarzy hitlerowskich, została potraktowana jako kwalifikowana postać przestępstwa zbrodni przeciwko ludzkości. Użyto tego pojęcia w akcie oskarżenia, zarzucając oskarżonym

2 S. Ziembicki, Kilka uwag o Rafale Lemkinie - twórcy pojęcia „,genocyd”, [w:] Wybitni prawnicy na przestrzeni wieków, red. M. Marszał, J. Przygodzki, Wrocław 2006, s. 252-255; R. Szawłowski, Rafat Lemkin - twórca pojęcia ,,ludobójstwo” i główny architekt Konwencji z 9 XII 1949 (w czterdziesta rocznicę śmierci), „Państwo i Prawo” 1999, nr 10, s. 74, 78-79.

3 S. Ziembicki, op. cit., s. 255-256; A. Spychalska, Rafat Lemkin - twórca pojęcia ,ludobójstwo", [w:] Acta Erasmiana, t. 2. Prace z myśli polityczno-prawnej oraz prawa publicznego, red. M. Sadowski, P. Szymaniec, Wrocław 2012, s. 162-163; J. Juszkiewicz, Adwokat Rafat Lemkin — twórca koncepcji prawnej zbrodni ludobójstwa, „Żydzi Wschodniej Polski”, seria 4. Uczeni żydowscy, red. G. Czerwiński, J. Ławski, Białystok 2016, s. 66. 
umyślne i systematyczne ludobójstwo, tj. eksterminację rasowych i narodowych grup ludności cywilnej pewnych okupowanych terytoriów, w celu zniszczenia określonych ras i klas ludności oraz grup narodowych, rasowych i religijnych, w szczególności Żydów, Polaków, Cyganów i innych ${ }^{4}$.

Zaprezentowane informacje mają niebagatelny wpływ na zrozumienie opisywanego problemu badawczego. Lemkinowska definicja genocydu będzie bowiem potrzebna do zrozumienia wydarzeń, które miały miejsce w latach 1943-1945 na terenach Galicji Wschodniej i Wołynia.

W czasie II wojny światowej główną ukraińską siłą polityczną była Organizacja Ukraińskich Nacjonalistów (dalej: OUN). Powstała ona w Wiedniu w 1929 roku na bazie Ukraińskiej Organizacji Wojskowej w połączeniu z Grupą Ukraińskiej Narodowej Młodzieży w Pradze, Legią Ukraińskich Nacjonalistów w Podiebradach i Związkiem Ukraińskiej Nacjonalistycznej Młodzieży we Lwowie. OUN była zwolenniczką radykalnego nacjonalizmu, a jej głównym ideologiem był Dymytro Doncow. Według niego najwyższą wartością była nacja, a najważniejszym celem zdobycie niezależnego państwa za wszelką cenę. Doncow nawoływał do mobilizowania człowieka do bezwzględnego działania w walce o wielką, niepodległą Ukrainę. Był zafascynowany ideologią faszystowską rozwijającą się w Europie, dlatego też — idąc za swoim ideologiem oraz wraz ze swoim rozwojem - OUN i jej największa grupa: frakcja Bandery (OUN-B) przybrały charakter faszystowski ${ }^{5}$.

Od samego początku OUN miała toczyć bezwzględną walkę ze wszystkimi zaborcami bez oglądania się na straty i przy użyciu wszelkich dostępnych metod. Miało to nastąpić na drodze permanentnej rewolucji, czyli stałego przygotowywania obywateli do narodowej rewolucji i przy użyciu propagandy, ale również poprzez terror i sabotaż. Ten radykalizm możemy również znaleźć w „,dekalogu nacjonalisty" autorstwa Stepana Łenkawskiego. Już w pierwszym przykazaniu czytamy: „Zdobędziesz państwo ukraińskie albo zginiesz, walcząc o nie”; siódme — „Nie zawahasz się dokonać najbardziej niebezpiecznego czynu” — według Grzegorza Motyki w pierwotnej wersji brzmiało „Nie zawahasz się spełnić największej zbrodni”; natomiast ósme to: „Nienawiścią i bezwzględną walką [i podstępem] będziesz przyjmował wroga Twego Narodu". Podobnie radykalne poglądy głosił kierownik referatu wojskowego OUN Mychajło Kołodzinśkyj. W broszurze o powstaniu styczniowym, wydanej pod pseudonimem M. Budżak, umieścił bardzo skrajne poglądy. Pisał:

Na przykładzie polskich powstańców widzieliśmy, że ludzie, którzy chcieli wolności dla swojego narodu, nie przebierali w środkach zmierzających do jej osiągnięcia. [...] Trzeba krwi,

4 J. Juszkiewicz, op. cit., s. 67.

5 W. Filar, Działania UPA przeciwko Polakom na Wotyniu iw Galicji Wschodniej w latach 1943-1944. Podobieństwa i różnice, [w:] Antypolska akcja OUN-UPA 1943-1944. Fakty i interpretacje, red. G. Motyka, D. Libionka, Warszawa 2002, s. 41; T. Stryjek, Europejskość Dymytra Doncowa, czyli o cechach szczególnych ideologii ukraińskiego nacjonalizmu, [w:] Antypolska akcja OUN-UPA..., s. 22. 
dajmy morze krwi, trzeba terroru, uczyńmy go piekielnym, trzeba poświęcić dobra materialne, nie zostawmy sobie niczego. Mając na celu wolne państwo ukraińskie, idźmy doń wszystkimi środkami i wszystkimi szlakami. Nie wstydźmy się mordów, grabieży i podpaleń. W walce nie ma etyki. Etyka to resztki niewolnictwa, narzuconego przez zwycięzców pokonanym. Nie dbajmy o dobre imię oraz opinię w świecie, bo jakbyśmy nie byli ideowi w naszej walce, to wszyscy i tak będą nas nazywać bandytami. Każda droga, która prowadzi nas do naszego najwyższego celu, bez względu na to, czy inni nazywają ją heroizmem, czy podłością, jest naszą drogą ${ }^{6}$.

M. Kołodzinśkyj po opuszczeniu więzienia został wysłany przez OUN do faszystowskich Włoch, gdzie Benito Mussolini wyraził zgodę na utworzenie obozów szkoleniowych dla nacjonalistów ukraińskich, jak również dla chorwackich ustaszy. Właśnie tam napisał dwie ważne dla działalności OUN prace. Pierwsza to referat Ukraińska nacjonalistyczna doktryna wojskowa, a druga Ukraińska doktryna wojenna. W obu tekstach przedstawiał kierunki przyszłego powstania, które miało doprowadzić do powstania państwa ukraińskiego. Kołodzinśkyj pisał, że powstanie powinno wybuchnąć jednocześnie w obu częściach Ukrainy i być zwrócone przeciwko ZSRS i Polsce. W pierwszym etapie miało być to wystąpienie chłopskie. Po opanowaniu kolejnych wsi, gmin i powiatów oddziały powstańcze miały ogłaszać powołanie państwa ukraińskiego i szybko się przeorganizowywać w regularną armię. Następnym krokiem miały być ataki na większe miasta. Walka powstańców miała być na śmierć i życie — ich albo Polaków i Rosjan. Walki miano prowadzić z bezwzględnością i okrucieństwem wobec przeciwników. Dalej pisał:

Nacjonalistyczne powstanie musi być wulkanem, w którym ma spłonąć wszystko, co wrogie — martwe i żywe. [...] W powstaniu na pierwsze miejsce wysuwa się okrucieństwo i nienawiść. [...] Tylko wtedy będziemy mieli moralną przewagę podczas powstania, jeśli wykażemy się większym okrucieństwem wobec nich. Masa chce zemsty [...] i nie należy przeszkadzać jej [...] wezwaniami miłości bliźniego.

\section{Kołodzinśkyj konstatował:}

Powstanie OUN ma zniszczyć żywe siły wroga na ziemiach ukraińskich. [...] Do tych sił należy obok armii regularnej cała wroga ludność i wszystkie te mniejszości, co odnoszą się wrogo do ukraińskiej niepodległości. Od zróżnicowania wrogów zależeć będzie sposób ich niszczenia. Wróg, który wystąpi wobec nas czynnie, musi być zniszczony fizycznie. [...] Polacy, Moskale oraz Żydzi, którzy czynnie będą nas zwalczać, muszą być zniszczeni. [...] Walka ma być bezlitosna, okrutna i zoologiczna. [...] Tylko podczas powstania będzie okazja, aby wymieść dosłownie do ostatniej nogi element polski z ZUZ (Ziem Zachodnioukraińskich) i w ten sposób skończyć z pretensjami co do polskiego charakteru tych ziem. Polski element, który będzie czynnie stawiać opór, musi ulec w walce, a resztę trzeba sterroryzować i zmusić do ucieczki za Wisłę. Bo nie można dopuścić do tego, aby po zdobyciu ZUZ element polski mógł tutaj żyć obok Ukraińców. ZUZ w przyszłym Państwie Ukraińskim musi być czysty pod

6 Za: G. Motyka, Wotyń '43, Kraków 2016, s. 26-28; zob. też idem, Od rzezi wotyńskiej do akcji ,,Wista”. Konflikt polsko-ukraiński 1943-1947, Kraków 2011, s. 25-26; W.A. Serczyk, Historia Ukrainy, Wrocław 1990, s. 416; W. Filar, op. cit., s. 42. 
względem narodowym. [...] Wobec wrogiego elementu należy wykazać się takim okrucieństwem w czasie powstania, aby jeszcze dziesiąte pokolenie bało się choćby popatrzeć w stronę Ukrainy, nie mówiąc już o ochocie dokonania jej podboju?

Koncepcje M. Kołodzinśkiego miały być zrealizowane w Galicji Wschodniej i Wołyniu w dramatycznych okolicznościach lat 1943-1945.

Wystąpienia ukraińskich nacjonalistów spod znaków OUN przeciwko ludności polskiej rozpoczęły się już w trakcie kampanii wrześniowej, a następnie po wybuchu wojny niemiecko-radzieckiej w 1941 roku. Ich apogeum nastąpiło natomiast w latach 1943-1945. Przyczyny i przebieg rzezi wołyńskiej i działań w Galicji Wschodniej zostały już przedstawione w pracach Władysława i Ewy Siemaszków ${ }^{8}$, Grzegorza Motyki, Grzegorza Hryciuka ${ }^{9}$, Władysława Filara ${ }^{10}$ czy świadków tamtych wydarzeń: Szczepana Siekierki, Henryka Komańskiego i Eugeniusza Różańskiego ${ }^{11}$.

Przygotowania do antypolskiej akcji rozpoczęły się w 1942 roku. W grudniu prowid OUN-B nakazał rozpoczęcie tworzenia partyzantki na terenie Wołynia. Na jej czele stanął Dmytro Klaczkiwśkyj — „Kłym Sawur”. W północno-wschodniej części Wołynia, gdzie siatką OUN-B kierował Iwan Łytwynczuk — „Dubowyj”, sformowano pierwszą sotnię pod dowództwem Hryhorija Perehiniaka pseud. „Dowbeszka-Korobka”. Formalnie była ona oddziałem wojskowym OUN, ale po podporządkowaniu pierwszej Ukraińskiej Powstańczej Armii (UPA) „Tarasa Bulby" Borowcia przyjęła nazwę Ukraińskiej Powstańczej Armii podporządkowanej OUN-B ${ }^{12}$.

Pierwsza sotnia Perehiniaka rozpoczęła działania wojskowe zwrócone przeciwko Polakom na Wołyniu. Najpierw rozbiła posterunek niemiecki we Włodzimiercu, a 9 lutego 1943 roku dokonała rzezi co najmniej 155 mieszkańców wsi Parośla I w powiecie sarneńskim, w tym 149 Polaków. Zostali oni zarąbani siekierami. Zabijanie przy pomocy siekier, kos, noży do obcinania buraków i innych narzędzi rolniczych powtarzało się przy kolejnych napadach ${ }^{13}$. Ewa Siemaszko

7 Za: G. Motyka, Wolyń..., s. 30-34.

8 W. Siemaszko, E. Siemaszko, Ludobójstwo dokonane przez nacjonalistów ukraińskich na ludności polskiej Wolynia 1939-1945, t. 1-2, Warszawa 2000.

9 G. Hryciuk, Przemiany narodowościowe i ludnościowe w Galicji Wschodniej i na Wotyniu w latach 1931-1948, Toruń 2005.

10 W. Filar, Wotyń 1939-1944. Eksterminacja czy walki polsko-ukraińskie. Studium historyczno-wojskowe zmagań na Wołyniu w obronie polskości, wiary i godności ludzkiej, Toruń 2003.

11 S. Siekierka, H. Komański, E. Różański, Ludobójstwo dokonane przez nacjonalistów ukraińskich na Polakach w województwie stanisławowskim 1939-1946, Wrocław 2007.

12 G. Motyka, Od rzezi..., s. 88-89.

13 G. Hryciuk, op. cit., s. 275; G. Motyka, Wotyń..., s. 48; M. Zajączkowski, Stosunki polsko-sowieckie na Wolyniu w świetle dokumentów czerwonych partyzantów, [w:] Sowieci a polskie podziemie 1943-1946. Wybrane aspekty stalinowskiej polityki represji, red. Ł. Adamski, G. Hryciuk, G. Motyka, Warszawa 2017 [e-book], akapit z przyp. 47; Ł. Adamski, Sowieckie relacje o rzezi wotyńskiej, [w:] Sowieci a polskie podziemie..., akapit z przyp. 49 i 10; E. Siemaszko, Bilans zbrodni, „Biuletyn Instytutu Pamięci Narodowej” 2010, nr 7-8, s. 84. 
wskazuje, że za likwidację ludności Parośli odpowiada UPA Maksyma Borowcia — „Tarasa Bulby”14. Władysław i Ewa Siemaszkowie podają także, że w pierwszym okresie ataków nacjonalistów ukraińskich dokonywanych do końca kwietnia 1943 roku zginęło około 4,4 tysiąca osób. W maju zamordowano 2025-2042, a w czerwcu - 2251 osób $^{15}$.

Rozmiary pierwszej fali ataków nie satysfakcjonowały „Kłyma Sawura”. Klaczkiwśkyj postanowił zatem odejść od taktyki „pełzających wystąpień” ogarniających kolejne miejscowości. Zdecydowano o zlikwidowaniu Polaków na całym Wołyniu w potężnym, synchronizowanym ataku ${ }^{16}$.

Tymczasem na wieść o pierwszych mordach na Wołyniu doszło do ostrego konfliktu między okręgowym delegatem Delegatury Rządu na Kraj Kazimierzem Banachem a komendantem Okręgu Wołyń AK płk. Kazimierzem Bąbińskim. Strona cywilna miała za złe strukturom AK, że nie skupiały się na obronie ludności cywilnej przed nacjonalistami ukraińskimi i zajmują się głównie przygotowaniami do wybuchu powstania powszechnego i rozprawy z Niemcami. Strona wojskowa zaś zarzucała delegaturze, że promuje tworzenie straży obywatelskich, w skład których wchodziliby Polacy i Ukraińcy. Zdaniem AK osłabiałyby one jedność i skuteczność struktur wojskowych. Banach realizował wytyczne gen. Stefana „Grota” Roweckiego, który nakazywał szukanie politycznego rozwiązania konfliktu. Wstępne rokowania między Delegaturą Rządu a UPA rozpoczęto 7 lipca 1943 roku w okolicach Świnarzyna; rozmowy miano kontynuować 10 lipca. Ze strony polskiej na spotkanie przybyli pełnomocnik Okręgowej Delegatury Rządu i zarazem dowódca Straży Chłopskiej na Wołyniu Zygmunt Rumel pseud. „Krzysztof Poręba”, przedstawiciel Okręgu Wołyńskiego AK Krzysztof Markiewicz pseud. „Czart” oraz ich przewodnik i woźnica Witold Dobrowolski. Niestety Ukraińcy nie chcieli rozmawiać, a odmowę wszelkich działań pojednawczych zamanifestowali bestialskim mordem całej polskiej delegacji ${ }^{17}$. Jak podaje Stanisław Jastrzębski, delegatów ostatecznie rozerwano końmi, a ich ciała poćwiartowano ${ }^{18}$.

Tragiczna śmierć członków Polskiego Państwa Podziemnego miała miejsce już w czasie upowskiej ofensywy. Została one przeprowadzona na niesłychaną skalę. Pierwsze wystąpienia nastąpiły w powiecie łuckim 4 i 5 lipca 1943 roku i objęły 26 jednostek administracyjnych. W ich trakcie zamordowano około 550 osób. Natomiast apogeum nastąpiło 11 lipca, kiedy w powiatach włodzimierskim i horochowskim zaatakowano 96 jednostek administracyjnych i zamordowano

14 E. Siemaszko, Ludobójcze akcje OUN-UPA w lipcu 1943 roku na Wotyniu, [w:] Antypolska akcja OUN-UPA..., s. 61.

15 W. Siemaszko, E. Siemaszko, op. cit., t. 2, s. 1045-1049.

16 G. Motyka, Wotyń..., s. 51.

17 G. Motyka, Od rzezi..., s. 134-137.

18 S. Jastrzębski, Ocalić od zapomnienia. Eksterminacja Polaków na Kresach Poludniowo-Wschodnich i Wotyniu w latach 1939-1946, Katowice 2016, s. 81. 
ponad 2,5 tysiąca ludzi. W czasie „akcji oczyszczającej” trwającej dwa miesiące (do końca sierpnia) mogło zginąć 18,8 tysiąca osób ${ }^{19}$.

W opisywanym okresie rzezie były przeprowadzane z niebywałym okrucieństwem. Oddziały UPA były wspomagane przez członków Kuszczowych Oddziałów Samoobrony (Samooboronni Kuszczowi Widdiły - SKW) oraz Ukraińców formalnie nienależących do zorganizowanych formacji, a uzbrojonych w siekiery, sprzęt rolniczy, drągi czy młoty do zabijania zwierząt. Ewa Siemaszko przedstawiła porażające opisy mordów znajdujących się w dokumentach polskiego podziemia:

We wszystkich, bez wyjątku, wsiach, osadach, koloniach akcję mordowania Polaków przeprowadzili z potwornym okrucieństwem. Kobiety — nawet ciężarne — przybijali bagnetami do ziemi, dzieci rozrywali za nogi, inne nadziewali na widły i rzucali przez parkany, inteligentów wiązali kolczastym drutem i wrzucali do studzien, odrąbywali siekierami ręce, nogi, głowy, wycinali języki, obcinali uszy i nosy, wydłubywali oczy, wyrzynali przyrodzenia, rozpruwali brzuchy i wywlekali wnętrzności, młotami rozbijali głowy, żywe dzieci wrzucali do płonących domów. Szał barbarii doszedł do tego stopnia, że żywych ludzi przerzynali piłami, kobietom obcinali piersi, inne nadziewali na pale lub uśmiercali kijami. Wielu ludzi skazywali na śmierć — z wyroku — odrąbując im ręce i nogi, a dopiero potem głowę ${ }^{20}$.

Jesienią 1943 roku fala mordów osłabła, jednak OUN-UPA postanowiła podjąć kolejną próbę eksterminacji ludności polskiej w czasie katolickiego Bożego Narodzenia. W tym czasie zamordowano 756-762 osoby ${ }^{21}$.

Reakcją ludności polskiej na mordy było tworzenie struktur obrony. Przybierały one postacie placówek albo baz samoobrony oraz oddziałów partyzanckich. Samoobrona była grupą zorganizowaną, uzbrojoną w broń palną i kierowaną przez jedną osobę albo komitet samoobrony, na przykład w Hucie Stepańskiej. Placówką samoobrony była miejscowość, w której bezpieczeństwa polskiej ludności pilnował oddział samoobrony. Bazą samoobrony zaś były zespoły polskich osiedli, wsi lub kolonii związanych wspólnym systemem obrony, które wzajemnie się wspierały i podejmowały wspólne akcje, na przykład Przebraże czy Huta Stepańska. Rzadkością było tworzenie samoobron w dużych miastach, ze względu na stacjonowanie tam wojsk niemieckich. Jeśli powstawały, to na przedmieściach (na przykład w Ostrogu, Dubnie, Rokitnie i Włodzimierzu Wołyńskim). Pierwsze grupy samoobrony powstały w styczniu 1943 roku w koloniach Zalesie i Zaułek w powiecie łuckim. Po wymordowaniu kolonii Parośla I w lutym 1943 roku w powiecie kostopolskim zorganizowano dziewięć samodzielnych placówek i dwie bazy samoobrony: w Hucie Stepańskiej i Wyrce, w powiecie sarneńskim — siedem samodzielnych placówek, a w powiecie łuckim — trzy placówki. Wraz z nasileniem eksterminacji polskiej ludności liczba samodzielnych placówek rosła i w maju liczyła 56, jednak już w grudniu 1943 roku było ich

19 G. Hryciuk, op. cit., s. 276; E. Siemaszko, Ludobójcze akcje..., s. 64.

20 E. Siemaszko, Ludobójcze akcje..., s. 63.

21 G. Hryciuk, op. cit., s. 276. 
tylko 14. Większą rolę odegrały bazy, których w 1943 roku było 15, a które objęły 95 placówek. W momencie wkroczenia Armii Czerwonej w styczniu 1944 roku nadal istniało trzynaście baz, lecz w kolejnych miesiącach zostały one zlikwidowane przez Sowietów ${ }^{22}$.

Władysław i Ewa Siemaszkowie podają, że maksymalna liczba istniejących jednocześnie placówek samoobrony i wchodzących w skład baz wynosiła 128 miało to miejsce w lipcu 1943 roku. Autorzy pisali, że:

w zestawieniu z blisko 3400 miejscowościami, w których żyli Polacy, i liczbą zamordowanych 50-60 tys. osób uświadamia [to] skromne rozmiary polskiej samoobrony. Gdyby samoobrona na Wołyniu była bardziej rozwinięta, a także gdyby była w stanie nie tylko przeciwstawiać się napadom OUN-UPA, a także prowadzić walki ofensywne i dokonywać akcji odwetowych nie byłoby na Wołyniu tylu ofiar ${ }^{23}$.

Pożoga zbrodniczej działalności ukraińskich nacjonalistów zaczęła docierać do Galicji Wschodniej. Pierwsze napady na Polaków, w których dochodziło do masowych mordów, rozpoczęły się jeszcze jesienią 1943 roku. Jednym z pierwszych był atak na wieś Netreba w województwie tarnopolskim, w którym zginęło 17 osób. Od tego momentu liczba napadów zaczęła gwałtownie rosnąć. Jedną z najdramatyczniejszych pacyfikacji była likwidacja polskiej samoobrony w Hucie Pieniackiej w lutym 1944 roku, dokonana wspólnie przez złożony z Ukraińców pododdział 4 pułku policyjnego SS, wspomagany przez sotnię „Siromanci” dowodzoną przez Dmytra Karpenkę pseud. „Jastrub”, wsławioną morderczymi rajdami w Galicji Wschodniej. W trakcie napadu zginęło od 600 do 1200 osób ${ }^{24}$.

Grzegorz Hryciuk, badając wielkość polskich strat w wyniku morderczych działań OUN-B i UPA w Galicji Wschodniej w latach 1943-1946, określił ich liczbę na 20-25 tysięcy osób, które poniosły śmierć, z czego w 1943 roku było to do dwóch tysięcy osób, w 1944 roku - 13-16 tysięcy, a w latach 1945-1946 - 5-6 tysięcy. Najwięcej ofiar pochodziło z województwa tarnopolskiego 13-16 tysięcy, następnie z lwowskiego - 5-6 tysięcy i stanisławowskiego 3-3,5 tysiąca. Czesław Blicharski szacuje straty w województwie tarnopolskim na co najmniej 14,6 tysiąca osób, a Stanisław Jastrzębski podaje liczbę około 11 tysięcy zamordowanych w województwie lwowskim w latach 1939-1947, wliczając $w$ tę liczbę ofiary konfliktu polsko-ukraińskiego na ziemiach dzisiejszej Polski w latach 1945-1947, w tym żołnierzy Wojska Polskiego i Milicji Obywatelskiej ${ }^{25}$. Z kolei Henryk Komański i Szczepan Siekierka w swojej książce Ludobójstwo dokonane przez nacjonalistów ukraińskich na Polakach w województwie

22 W. Siemaszko, E. Siemaszko, op. cit., t. 2, s. 1064-1067.

23 Ibidem, s. 1067.

24 G. Motyka, Ukraińska partyzantka 1942-1960. Działalność Organizacji Ukraińskich Nacjonalistów i Ukraińskiej Powstańczej Armii, Warszawa 2015, s. 381-383.

25 G. Motyka, Ukraińska partyzantka..., s. 410-411. 
tarnopolskim 1939-1946 podają liczbę 24 tysięcy zabitych w województwie tarnopolskim, z czego ponad 11 tysięcy znanych z imienia ${ }^{26}$.

Opisane tragiczne wydarzenia na Wołyniu i w Galicji Wschodniej ewidentnie wyczerpują znamiona lemkinowskiej definicji genocydu, która znalazła się w Konwencji o zapobieganiu i karaniu zbrodni ludobójstwa przyjętej przez Zgromadzenie Ogólne ONZ z dnia 9 grudnia 1948 roku. Takie spojrzenie na działalność OUN i UPA znajdziemy również w publikacjach Siemaszków ${ }^{27}$ czy Bogusława Kuźniara ${ }^{28}$.

Tymczasem nocą z 3 na 4 stycznia 1944 roku Armia Czerwona przekroczyła granice II Rzeczypospolitej w okolicach Rokitna, a 2 lutego zajęła Równe. W połowie stycznia komendant Okręgu AK Wołyń płk K. Bąbiński wydał rozkaz przystąpienia do realizacji planu „Burza”. Od połowy lutego oddziały AK zaczęły się przeformowywać w 27. Wołyńską Dywizję Piechoty AK. Walczyła ona nie tylko z Niemcami, ale i nacjonalistami ukraińskimi. Wspólnie z Armią Czerwoną zajęła Kowel. Niestety po zajęciu Wołynia część dywizji wycofała się w lipcu za Bug, a część oddziałów zostało rozformowanych; oficerów najczęściej aresztowali Sowieci ${ }^{29}$.

Zajęcie Wołynia i następnie Galicji Wschodniej przez Armię Czerwoną wprowadzało nową sytuację polityczną. Sowieci zaczęli tworzyć swoją administrację, ale stali się również obiektami ataków UPA. Słynna stała się śmierć gen. Nikołaja Watutina w kwietniu 1944 roku, który zmarł w wyniku ran odniesionych w potyczce z Ukraińcami. Sowieci postanowili zatem przystąpić do likwidacji oddziałów OUN-UPA. Poważanym kłopotem dla Polaków był też pobór mężczyzn do armii Berlinga. Pod broń mieli trafić poborowi z roczników 1894-1926. W tej sytuacji na wsiach zostawali jedynie starsi mężczyźni i młodzież. Stanowiło to ogromne zagrożenie dla wiejskiej ludności polskiej, której nie miał kto bronić przed napadami nacjonalistów ukraińskich ${ }^{30}$.

W takich okolicznościach Sowieci zaczęli tworzyć formacje milicji pomocniczej tak zwanych Istriebitielnych Batalionów. Koncepcja ich powołania powstała po ataku Niemiec na ZSRR, a utworzono je na mocy rozkazu Rady Komisarzy Ludowych z dnia 24 czerwca 1941 roku. Dowództwo nad IB sprawowali funkcjonariusze formacji Ludowego Komisariatu Spraw Wewnętrznych Związku

26 H. Komański, S. Siekierka, Ludobójstwo dokonane przez nacjonalistów ukraińskich na Polakach w województwie tarnopolskim 1939-1946, Wrocław 2004, s. 989, 1167.

27 W. Siemaszko, E. Siemaszko, op. cit., t. 1, s. 11-14; E. Siemaszko, Genocidium atrox, „Do Rzeczy. Historia” 5, 2013.

28 B. Kuźniar, Dowody zbrodni nacjonalistów ukraińskich na ludności polskiej w latach 19391947 oraz ich ocena w świetle prawa krajowego i międzynarodowego, „Przegląd Geopolityczny” 2015, nr 12, s. 65-69.

29 G. Motyka, Od rzezi..., s. 185-198; M. Semczyszyn, Nikita Chruszczow wobec Polaków i polskiego podziemia na Wotyniu i w Galicji Wschodniej w latach 1943-1945, [w:] Sowieci a polskie podziemie..., akapit z przyp. 41.

30 S. Jastrzębski, Kresy wschodnie we krwi. Rzecz o polskiej samoobronie, Wrocław 2001, s. $62-63$. 
Socjalistycznych Republik Radzieckich (NKWD) ${ }^{31}$. W tamtym okresie w ich skład weszli sowieccy aktywiści, lojalni robotnicy i urzędnicy, a także kołchoźnicy. Bataliony otrzymały rozkaz likwidacji wrogich dywersantów, łącznościowców, radiooperatorów i spadochroniarzy, a także zabezpieczania zakładów przemysłowych, mostów i innych obiektów strategicznego znaczenia. Miały również wspierać oddziały NKWD w tropieniu i ściganiu elementu antysowieckiego. Z wewnętrznych statystyk NKWD wynikało, że do 1 sierpnia 1941 roku powstało 1775 IB, liczących 328450 członków. Otrzymali oni rozkaz, że po wycofaniu się Armii Czerwonej mają pozostać na tych terenach i wspierać ruch oporu. Na Ukrainie 1 października 1941 roku operowało 139 batalionów niszczycielskich, złożonych z 25188 ludzi. Z biegiem czasu IB zostały wcielone do Armii Czerwonej ${ }^{32}$.

Istriebitielne Bataliony działające na terenie Wołynia i Galicji Wschodniej powstawały od wiosny 1944 roku z członków samoobron powstałych w czasie rzezi 1943 roku dokonywanych przez Ukraińców. Sowieci nie chcieli tolerować ich działalności, więc członkowie samoobron, chcąc zachować prawo do posiadania broni, decydowali się na wstąpienie do IB. Również część oddziałów AK ujawnionych w czasie akcji „Burza”, po wejściu armii radzieckiej, zasiliła Istriebitielne Bataliony, za zgodą dowództwa. Miało to miejsce między innymi w Kołomyi, Zabłociu i Śniatynie. Trafiali tam także mężczyźni przymusowo kierowani przez „wojenkomaty”, czyli komisje uzupełnień. Do IB wstępowali ponadto ochotnicy, zazwyczaj młodzież siedemnasto- i osiemnastoletnia, która nie została powołana do 1 Armii Wojska Polskiego ${ }^{33}$.

Jak pisze Tomasz Balbus, w sierpniu kpt. Zygfryd Szynalski pseud. „Tryk”, wybitny oficer Kedywu w Inspektoracie Brzeżany AK, ujawnił się i został dowódcą IB w Brzeżanach. Podlegał on bezpośrednio tamtejszej placówce NKWD. Batalion tworzyli głównie żołnierze AK z Brzeżan i okolic. Jednostka ta nie tylko ochraniała polską ludność przed UPA, ale dokonywała też akcji pacyfikacyjnych i zaczepnych przeciwko nacjonalistom ukraińskim. Z biegiem czasu kpt. Szynalski był wzywany kilkukrotnie do siedziby NKWD i ostatecznie 30 listopada 1944 roku zmuszono go do podpisania zobowiązania do współpracy agenturalnej. Otrzymał pseudonim „Zakordonnyj”, ale współpracy nigdy nie podjął; następnie zbiegł do Lwowa, gdzie działał w strukturach konspiracyjnej organizacji „Nie”34.

Stanisław Siekierka, żołnierz AK zaprzysiężony w styczniu 1944 roku, tak wyjaśniał Piotrowi Zychowiczowi, autorowi artykułu $Z$ wrogiem na wroga, swoje wstąpienie do IB:

31 J. Rutkiewicz, W.N. Kulikow, Wojska NKWD 1917-46, Warszawa 1998, s. 29-31.

32 B. Musiał, Sowieccy partyzanci 1941-1944. Mity i rzeczywistość, przeł. z jęz. niem. E. Stefańska, Poznań 2014, s. 74-75.

${ }^{33}$ G. Motyka, Ukraińska partyzantka..., s. 398-399; S. Jastrzębski, Ludobójstwo ludności polskiej przez OUN-UPA w województwie stanisławowskim w latach 1939-1946, Warszawa 2004, s. 51; idem, Oko w oko z banderowcami, Wrocław 2010, s. 101-102.

34 T. Balbus, Polskie ,Istriebitielne bataliony” NKWD w latach 1944-1945, „Biuletyn Instytutu Pamięci Narodowej” 2002, nr 6, s. 72-73. 
Pyta Pan, jak polscy patrioci mogli wstąpić do sowieckich batalionów szturmowych? Oto odpowiedź. Uważaliśmy, że to jedyny sposób na uchronienie naszych rodzin przed straszliwą śmiercią. Dla nas liczyło się to, że bolszewicy wydali nam karabiny i dzięki temu mogliśmy bronić naszych wsi i naszych rodzin. Wielką politykę odsunęliśmy na bok. My musieliśmy działać tu i teraz ${ }^{35}$.

\section{Podobnie relacjonował Tadeusz Banasiewicz:}

— Nie będę ukrywał: byliśmy zachwyceni, że ktoś dał nam do ręki broń. Kto to zrobił, nie miało dla nas znaczenia. Gdy dostałem karabin, wiedziałem już, że nie zostanę zarżnięty jak prosię. Od razu zdecydowałem, że ostatni pocisk zostawiam dla siebie. Że nie dostanę się w ich ręce żywcem.

- Czy z rąk Ukraińców zginął ktoś z pańskiej rodziny?

— Tak, oboje rodziców. Ja z bratem w ostatniej chwili uciekliśmy do lasu ${ }^{36}$.

Stanisław Jastrzębski, żołnierz IB, pisał, że szkolenie trwało około trzech tygodni. Żołnierze uczyli się regulaminów obowiązujących w Armii Czerwonej, posługiwania się bronią i materiałami wybuchowymi. Nie składali jednak radzieckiej przysięgi wojskowej i nie otrzymywali radzieckich mundurów. Zazwyczaj nosili ubrania cywilne lub półwojskowe, a na głowach mieli polskie rogatywki lub furażerki - obowiązkowo $\mathrm{z}$ orzełkiem. IB dowodzone były przez zawodowych oficerów radzieckich, kierowanych tam z wojenkomatów. Zdarzało się, że dowodzili nimi funkcjonariusze operacyjni NKWD. Wynika to na przykład z relacji Kazimierza Ciechanowskiego ${ }^{37}$.

Wraz z odsunięciem się frontu z terenów Galicji Wschodniej nacjonaliści ukraińscy podjęli wzmożone akcje przeciwko Polakom. Dowódca UPA „Zachód” Wasyl Sydor „Szełest” w rozkazie nr 6 z 10 lipca 1944 roku polecał:

Rozkazuję uderzać stale na Polaków do ostatecznego wyniszczenia ich z tych ziem. Kolejność akcji przeciwpolskich: a) niszczenie siły bojowej wroga, b) aktywiści i seksoci [tajni współpracownicy - M.M.K., J.P.], c) akcje odwetowe. Formy: a) wspólna akcja oddziałów na skupiska polskie, b) akcja niepokojąca pododdziałów, czujek itd. Tak jak i przedtem nie wolno likwidować kobiet i dzieci. W pewnych wypadkach wzywać Polaków do terminowego opuszczenia ukraińskich ziem ${ }^{38}$.

Działania UPA wymykały się jednak z ram rozkazów „Szełesta”. Przykładem może być napad na wsie Ubynie i Dziedziłów przeprowadzony w nocy z 5 na 6 sierpnia 1944 roku przez piętnastoosobowy oddział UPA, który zamordował 4 mężczyzn, 18 kobiet i 5 dzieci. Kobiety ginęły również w ataku na wieś Kurzany w powiecie Brzeżany ${ }^{39}$.

35 P. Zychowicz, Z wrogiem na wroga, „Rzeczpospolita” 16.01.2010.

36 Ibidem.

37 S. Jastrzębski, Kresy wschodnie..., s. 68-69, 104-106.

38 G. Hryciuk, Akcje UPA przeciwko Polakom po ponownym zajęciu Wolynia i Galicji Wschodniej przez Armię Czerwona w 1944 roku, [w:] Antypolska akcja OUN-UPA..., s. 106.

39 Ibidem, s. 108. 
W okolicznościach wzmożenia ataków UPA Istriebitielne Bataliony zajmowały się zarówno obroną polskiej ludności i jej mienia przed ludobójstwem i grabieżami dokonywanymi przez nacjonalistów, jak i zwalczaniem ukraińskiego podziemia - byli wysyłani na akcje pacyfikacyjne w rejony koncentracji oddziałów UPA. Ochraniały także obiekty państwowe i gospodarcze oraz utrzymywały ład i porządek publiczny. Działania IB wspierały Armia Czerwona oraz siatka agenturalna sowieckich służb bezpieczeństwa. Istriebitielne Bataliony w dużym stopniu przyczyniły się do uratowania życia i mienia tysięcy Polaków ocalałych z pogromu przeprowadzonego przez Ukraińców, a niektórzy z nich szukali w Batalionach także zemsty za śmierć bliskich w czasie rzezi wołyńskiej i galicyjskiej. Istnienie IB traktowane było przez UPA jako poważne zagrożenie. Grzegorz Motyka podaje treść jednego z raportów UPA:

Bardzo niebezpiecznym dla nas przeciwnikiem jest polska policja — zna miejsca i ludzi [...] bierze udział w antyukraińskich operacjach milicji bolszewickiej. Dlatego te [oddziały] polskiej policji, które otwarcie współpracują z bolszewikami, zwalczamy ${ }^{40}$.

Cytowany autor podaje również treść specinformacji napisanej przez prokuratora obwodu drohobyckiego Krygina do sekretarza obkomu Ołeksenki z dnia 13 listopada 1944 roku w sprawie działalności IB w rejonie Komarna, złożonego tylko z Polaków. Krygin pisał:

a) żołnierze Istriebitielnego Batalionu w czasie wyjazdów na operacje w ukraińskich wioskach bili ludność ukraińską,

b) podczas prowadzonych operacji zabierali obywatelom majątek, nie mając do tego żadnych podstaw,

c) palili domy pod pretekstem, że to mieszkania członków banderowskich band, nie mając do tego żadnych podstaw,

d) przebywając w wioskach [...] żołnierze Istriebitielnego Batalionu nazywali Ukraińców bandytami, banderowcami,

e) podczas podpalania domów w jednym z nich spalili żywcem dwie kobiety, a jednego mężczyznę ranili w rękę ${ }^{41}$.

Oceniając przytoczony dokument, należy pamiętać, że żołnierzami IB często byli bezpośredni świadkowie eksterminacji ludności polskiej na Wołyniu i w Galicji Wschodniej, którzy nierzadko stracili wielu członków swoich rodzin. Z psychologicznego punktu widzenia mogły się więc zdarzać zachowania odwetowe. Należałyby zadać pytanie, czy bez działań IB liczba zamordowanych Polaków mogła być większa? Według autora cytowanego artykułu odpowiedź jest jedna - na pewno tak. Grzegorz Motyka opisuje kilka ataków UPA na polskie miejscowości, na przykład na Czerwonogród, gdzie silny oddział IB opiekował się około 1500 Polakami. W trakcie ataku zginęło 49 cywili, a 28 zostało rannych. Można

\footnotetext{
${ }^{40}$ G. Motyka, Od rzezi..., s. 337-338.

41 G. Motyka, Ukraińska partyzantka..., s. 400.
} 
się tylko domyślać, ilu byłoby zabitych, gdyby nie obecność żołnierzy Istriebitielnego Batalionu ${ }^{42}$.

Liczebność IB szacuje się na 212 batalionów, w których służyło 23906 osób ${ }^{43}$. Ze sprawozdań sowieckich wynika, że Istriebitielne Bataliony działające w Ukraińskiej Socjalistycznej Republice Radzieckiej od 1 stycznia 1944 do 1 sierpnia 1945 roku (kiedy większość polskich „istriebków” została ekspatriowana z rodzinami do Polski) przeprowadziły 26328 operacji bojowych mających na celu „likwidację band”. W tym czasie zabily 11193 osoby i aresztowały 173580 osób; 11094 osoby zaliczono do kategorii „bandytów i pomocników”, do tej samej kategorii zaliczono 30366 aresztowanych. Spośród innych aresztowanych największą liczbę stanowili między innymi dezerterzy z Armii Czerwonej (42 217), uchylający się od służby wojskowej (33 940), „dezerterzy” z robót przymusowych (22 609) oraz spekulanci $(9322)^{44}$.

Wiosną 1945 roku sowieckie władze bezpieczeństwa zaczęły demobilizować polskie Istriebitielne Bataliony. Było to związane z akcją ekspatriacji Kresowiaków na tereny Polski. Walkę z ukraińskimi podziemiem kontynuowali Ukraińcy wcielani do IB oraz sowieckie służby bezpieczeństwa. Ostatecznie, Decyzją Centralnego Komitetu Komunistycznej Partii (bolszewików) Ukrainy z 1 czerwca 1948 roku, Istriebitielne Bataliony zostały zastąpione Uzbrojonymi Grupami dla Ochrony Społecznego Porządku ${ }^{45}$.

Do ostatecznej oceny Istriebitielnych Batalionów niech służy cytat pochodzący z pracy Władysława i Ewy Siemaszków:

Zajmowaniu Wołynia przez Sowietów towarzyszyła mobilizacja wszystkich mężczyzn zdolnych do noszenia broni do wojska. Polaków kierowano do 1. Armii Wojska Polskiego, niektórych do Armii Czerwonej, natomiast młodzież w wieku 16-17 lat została wcielona do Istriebitielnych Batalionów. Bataliony te były wówczas jedyną siłą chroniącą przed napadami nacjonalistów ukraińskich przebywające na Wołyniu polskie rodziny, które po odejściu do wojska mężczyzn były zupełnie bezbronne ${ }^{46}$.

\section{2.}

Konstytucja RP z 1997 roku podkreśla szczególne znaczenie walki o niepodległość i rolę, jaką w tym procesie odegrali weterani. Opieka nad weteranami jest jednym z podstawowych celów państwa. Zgodnie z art. 19 „Rzeczypospolita

42 Ibidem, s. 406-407.

43 G. Hryciuk, Przemiany narodowościowe..., s. 289.

44 G. Motyka, Od rzezi..., s. 339; I. Iljuszyn, Sowieckie represje wobec ludności ukraińskiej i polskiej na zachodnim Wotyniu i Galicji Wschodniej (w latach 1944-1946), [w:] Sowieci a polskie podziemie..., akapit z przyp. 26.

45 T. Balbus, op. cit., s. 75.

46 W. Siemaszko, E. Siemaszko, op. cit., t. 2, s. 1055. 
Polska specjalną opieką otacza weteranów walk o niepodległość, zwłaszcza inwalidów wojennych" 47 . Przepis ten jest zasadą ustrojową wyrażającą nakaz otoczenia opieką weteranów walk o niepodległość. Zasada ta nawiązuje wprost do preambuły Konstytucji, w myśl której naród okazuje wdzięczność przodkom za „walkę o niepodległość okupioną ogromnymi ofiarami”.

Zasady konstytucyjne są podstawową wskazówką do określenia aksjologii konstytucji, czyli „wskazania systemu wartości wynikającego z całokształtu postanowień konstytucji i determinującego jej szczegółowe unormowania"48. Aksjologia ustawy zasadniczej determinuje jej materialną tożsamość ${ }^{49}$. Odtworzenie kompleksowej aksjologii konstytucyjnej zawsze wymaga uwzględnienia tych norm, które w sposób bezpośredni lub pośredni wyrażają ideę ochrony określonych zasad i wartości ${ }^{50}$. Ze względu na hierarchię norm konstytucyjnych opieka nad weteranami walk o niepodległość jest istotną wartością konstytucyjną; stanowi ważny fundament tożsamości Rzeczypospolitej ${ }^{51}$.

Adresatem obowiązków wynikających z nakazu zapewnienia weteranom „specjalnej opieki” jest „Rzeczpospolita Polska”, czyli zarówno wszystkie organy władzy publicznej, działające w zakresie swoich kompetencji, właściwe instytucje, jak i obywatele i podmioty podobne ${ }^{52}$. W świetle postanowień Konstytucji państwo polskie jest bowiem traktowane jak wspólnota obywatelska (res publica), nie zaś jak zespół organów (instytucji) sprawujących władzę nad obywatelami. Wszystkie zadania należące do państwa Konstytucja powierza Rzeczypospolitej — wspólnocie wszystkich obywateli. Przy tym „Rzeczpospolita” nie

47 Zdaniem K. Complaka przepis ten powinien zostać uchylony. „Zakłada on, ni mniej, ni więcej — jak przystało na dokument pomyślany na dłuższy czas obowiązywania — stałe (częste) prowadzenie walk o niepodległość oraz - co jest jeszcze ciekawsze - uciekanie się do wojny zakazanej przez prawo międzynarodowe. Innymi słowy, po ponownym odzyskaniu niepodległości przez Polskę w 1989 r. nasuwa się pytanie: o jakich kombatantach walk o niepodległość będzie mowa w tym artykule za pół wieku? Poza tym — o jakich wojnach, skoro — nawet jeśli doszłoby do materializacji takich zjawisk - mielibyśmy do czynienia jedynie z wojną obronną, trudną w chwili obecnej do wyobrażenia w ramach tak ukształtowanej Europy, albo z interwencjami pokojowymi naszych żołnierzy, którzy mogliby być ofiarami takich działań" — idem, Komentarz do art. 19 Konstytucji, [w:] Konstytucja Rzeczypospolitej Polskiej. Komentarz, red. M. Haczkowska, Warszawa 2014, s. 33-34.

48 L. Garlicki, Polskie prawo konstytucyjne. Zarys wyktadu, Warszawa 2020, s. 56.

49 Zob. K.M. Ujazdowski, Tożsamość i funkcjonowanie Konstytucji Rzeczypospolitej Polskiej z 2 kwietnia 1997 roku, „Prawo i Więź” 2014, nr 2, s. 7; J. Jaskiernia, Funkcje Konstytucji RP w dobie integracji europejskiej i radykalnych przemian politycznych, Torun 2020, s. 122-125.

50 Por. M. Florczak-Wątor, Horyzontalny wymiar praw konstytucyjnych, Kraków 2014, s. 228 n.

51 Zob. wyrok Trybunału Konstytucyjnego z dnia 9 marca 2004 roku, sygn. K 12/02, OTK ZU 2004, seria A, nr 3, poz. 19; zob. też M. Kordela, Zasady prawa. Studium teoretycznoprawne, Poznań 2012, s. 126-127.

52 Zob. L. Garlicki, M. Derlatka, Komentarz do art. 19 Konstytucji, [w:] Konstytucja Rzeczypospolitej Polskiej. Komentarz, red. L. Garlicki, M. Zubik, t. 1, Warszawa 2016, s. 3. 
oznacza władzy państwowej, lecz stanowi zorganizowane państwo obywatelskie, jest dobrem wspólnym wszystkich obywateli ${ }^{53}$.

Substrat Rzeczypospolitej to dobro wspólne; kształtuje ono jedność państwa. Rzeczypospolita uznaje podmiotowość ludzi, ich godność, będącą źródłem wszelkich wolności i praw człowieka. Poszanowanie i ochrona godności są obowiązkami władz publicznych. Miarą i tworzywem państwa — dobra wspólnego — jest człowiek, prawo jest tworzone dla człowieka i ma służyć jego dobru. Państwo widziane jako dobro wspólne ma służyć sprawiedliwie wszystkim członkom społeczności państwowej, przy czym ma przejawiać pamięć i troskę o uczestników walk w obronie Rzeczypospolitej.

Trybunał Konstytucyjny w wyroku z 23 września 1997 roku (sygn. K 25/96) ${ }^{54}$ stwierdził, że celem przyznanych i gwarantowanych ustawowo kombatantom uprawnień jest „uhonorowanie zasług obywateli polskich, którzy walczyli o suwerenność i niepodległość Ojczyzny przez walkę zbrojną lub działalność cywilną". Jednocześnie zdefiniował podstawowe zasady, które powinny charakteryzować treść regulacji ustawowej. Wskazał, że

wszyscy kombatanci powinni być traktowani z jednakowym szacunkiem i równą troską. Uprawnienia przewidziane $\mathrm{w}$ ustawie powinny zatem obejmować na tych samych zasadach wszystkie osoby, które uzyskały potwierdzenie działalności kombatanckiej bez szczególnego faworyzowania lub dyskryminowania niektórych z nich.

W ocenie Trybunału ustawodawca w zakresie przyjmowanych rozwiązań musi się kierować zasadą sprawiedliwości identyfikowanej z takim działaniem ustawodawcy, który stanowi regulacje ustawowe, mając na celu dobro człowieka i zapewnienie mu odpowiednich warunków (tu: szczególnej opieki) dla jego egzystencji i rozwoju w ramach kreowanych struktur społecznych i ekonomicznych. W takim znaczeniu odwołanie się do pojęcia sprawiedliwości musi pozostawać w związku z ogólnym kierunkiem aksjologicznym przyjętym w istniejącym systemie prawa (zwłaszcza w treści Konstytucji), przede wszystkim zaś z tymi wartościami, którym przyznaje się charakter przewodni - w omawianym zakresie z szacunkiem dla poświęcenia tych osób, które narażając swoje życie i zdrowie, uczestniczyły w walce o niepodległość Polski ${ }^{55}$. W preambule do ustawy z dnia 24 stycznia 1991 roku o kombatantach oraz niektórych osobach będących ofiarami represji wojennych i okresu powojennego ${ }^{56}$ (dalej: ustawa o kombatantach) czytamy, że: „Kombatantom oraz ofiarom represji należny jest głęboki szacunek

53 Zob. A. Ławniczak, M. Masternak-Kubiak, Republikańska forma państwa w ujęciu Konstytucji RP, „Państwo i Prawo” 1999, nr 8, s. 50-51.

54 OTK 1997, nr 3-4, poz. 36.

55 Zob. M. Jabłoński, Prawo weteranów do specjalnej opieki ze strony państwa, [w:] Realizacja i ochrona konstytucyjnych wolności i praw jednostki w polskim porzadku prawnym, red. M. Jabłoński, Wrocław 2014, s. 612-613.

56 Tekst jedn. Dz.U. z 2020 r. poz. 517. 
wszystkich rodaków oraz szczególna troska i opieka ze strony instytucji państwowych, samorządów terytorialnych i organizacji społecznych".

Podmiotem uprawnień wynikających z art. 19 Konstytucji są przede wszystkim „weterani walk o niepodległość” 57 . Na pewno „weteranem” może być tylko osoba, która aktywnie uczestniczyła w określonym procesie historycznym w „walce o niepodległość". Ustawa zasadnicza posługuje się szerokim pojęciem weterana, co oznacza, że może nim być zarówno osoba, która brała udział w działaniach wojennych, jak i taka, która uczestniczyła w walce o niepodległość w czasie, w którym nie toczyły się już działania wojenne ${ }^{58}$. Oznacza to objęcie opieką tej kategorii osób, które po II wojnie światowej uczestniczyły w działaniach przeciwko władzy ludowej, kontynuując walkę o odzyskanie przez Polskę pełnej suwerenności ${ }^{59}$. Uzasadnienie takiego stanowiska można odnaleźć w przywoływanej już treści preambuły do Konstytucji. Ustrojodawca sam stwierdza, że „Ojczyzna nasza odzyskała dopiero w 1989 roku możliwość suwerennego i demokratycznego stanowienia o swoim losie". Z tego też powodu możemy mówić o pewnym przedziale czasowym - a w konsekwencji kwalifikować określonego rodzaju działalność i jej skutki nakierowane na odzyskanie możliwości suwerennego i demokratycznego stanowienia - z walką o niepodległość Rzeczypospolitej Polskiej ${ }^{60}$.

Przepis art. 19 nie obejmuje natomiast swym zakresem podmiotowym osób, które podlegały represjom wojennym i okresu powojennego z innych przyczyn niż działalność polityczna, religijna lub inna związana z walką o suwerenność i niepodległość Polski. Jeśli walka nie miała na celu odzyskania niepodległości, to udział $\mathrm{w}$ niej nie stanowi podstawy do nabycia statusu weterana ${ }^{61}$. Trzeba przy tym mieć na względzie, że odwołanie poczynione w preambule Konstytucji

57 Zob. E. Łętowska, Uwagi o weryfikacji kombatantów, [w:] Prawo pracy a wyzwania XXI wieku, kom. red. M. Matey-Tyrowicz, L. Nawacki, B. Wagner, Warszawa 2002, s. 45 n.

58 Zob. wyrok Trybunału Konstytucyjnego z dnia 15 kwietnia 2003 roku, sygn. SK 4/02, OTK ZU 2003, nr 4, poz. 31.

59 Zob. M. Jabłoński, op. cit., s. 609.

${ }^{60}$ Należy zaznaczyć, że skoro niepodległość już została uzyskana, to w obecnej sytuacji historycznej kategoria „weteranów” ma charakter zamknięty i nie może ulegać rozszerzaniu. Zob. J. Boć, [w:] Konstytucje Rzeczypospolitej oraz komentarz do Konstytucji RP z 1997 roku, red. J. Boć, Wrocław 1998, s. 49; zob. też L. Garlicki, M. Derlatka, op. cit., s. 3-4.

61 Trzeba mieć na uwadze, że w ustawie o kombatantach do Korpusu Weteranów Walk o Niepodległość RP zaliczono wszystkich „kombatantów” zdefiniowanych jako osoby, które „brały udział w wojnach, działaniach zbrojnych i powstaniach narodowych, wchodząc w skład formacji wojskowych lub organizacji walczących o suwerenność i niepodległość Rzeczypospolitej Polskiej” oraz dodano ofiary represji prowadzące działalność równorzędną z działalnością kombatancką w rozumieniu ustawy, przy czym działalność równorzędna musiała polegać na czynie zbrojnym (art. $6^{2}$ w zw. z art. 1 i art. 2 pkt 2 oraz pkt 4-6 ustawy o kombatantach). Natomiast ustawa wykluczyła $\mathrm{z}$ tego grona pozostałe osoby represjonowane (na przykład prowadzące tajne nauczanie czy więźniów obozów koncentracyjnych). Zob. wyrok Trybunału Konstytucyjnego z dnia 19 grudnia 2012 roku, sygn. K 9/12, OTK-A 2012, nr 11, poz. 136; zob. też L. Garlicki, M. Derlatka, op. cit., s. 3-4. 
wyraźnie wskazuje sensu largo na wdzięczność przodkom „za walkę o niepodległość okupioną ogromnymi ofiarami”. To odwołanie do przodków w zasadzie powinno determinować kierunek interpretacji zakresu podmiotowego „weteranów walk o niepodległość" w stronę tych wszystkich, którzy czynnie uczestniczyli w działaniach identyfikowanych z walką o niepodległość Polski ${ }^{62}$.

Zaznaczyć też trzeba, że deklaracja ustrojodawcy zawarta w art. 19 jest postanowieniem formułującym prawo podmiotowe ${ }^{63}$. Publiczne prawa podmiotowe są charakterystyczne dla opisywania sytuacji między jednostką a państwem. Ich istnienie ma na celu ochronę interesów jednostki, która w ramach unormowań publicznoprawnych ma słabszą pozycję wobec podmiotów władzy. Konstrukcja tych praw określa obowiązek ciągłego analizowania konkurujących z sobą interesów indywidualnego i publicznego ${ }^{64}$. Publicznym prawem podmiotowym określa się prawo do żądania: wydania aktu prawnego, określonych świadczeń pozytywnych, zaniechania działań ze strony władzy w sferę wolności jednostki, a także współdziałania $\mathrm{z}$ administracją $\mathrm{w}$ załatwianiu spraw publicznych. Treścią publicznego prawa podmiotowego jest możliwość skutecznego domagania się jednostki od państwa lub wspólnoty samorządowej, za pomocą zindywidualizowanego roszczenia, ściśle określonego zachowania, odpowiadającego interesowi prawnemu żądającego ${ }^{65}$.

3.

W zakresie konstytucyjnego pojęcia „weteranów walk o niepodległość" mieszczą się nie tylko kombatanci, ale i osoby prowadzące określoną działalność kombatancką.

„Kombatant” to ,żołnierz biorący czynny udział w walce”, w potocznym znaczeniu ktoś zasłużony „dla sprawy”66. Kombatant to przy tym osoba uprawniona do walki w świetle prawa międzynarodowego, które stanowi, że w skład sił zbrojnych wchodzą zarówno osoby o statusie kombatantów, jak i niekombatantów.

${ }^{62}$ Zdaniem L. Garlickiego i M. Derlatki wskazane w art. 19 „walki o niepodległość” muszą być powiązane z niepodległością Polski. Nie ma zatem podstaw, aby art. 19 odnosić do uprawnień osób, które walczyły o niepodległość innych państw czy narodów, wprowadzając oddzielną grupę „,weteranów", wykraczającą poza zakres wyznaczony przez art. 19 Konstytucji. Zob. eidem, op. cit., s. 4-5.

63 Zob. wyrok Trybunału Konstytucyjnego z dnia 15 kwietnia 2003 roku, sygn. SK 4/02, OTK ZU 2003, nr 4, poz. 31.

64 Zob. J. Człowiekowska, Prawo do sądu jako publiczne prawo podmiotowe, „Zeszyty Naukowe Uniwersytetu Jagiellońskiego" 2006, nr 5, s. 175-184.

65 Zob. W. Jakimowicz, Publiczne prawa podmiotowe, Warszawa 2002, s. 246.

66 Zob. I. Jędrasik-Jankowska, Ustawa o kombatantach oraz niektórych osobach będacych ofiarami represji wojennych i okresu powojennego. Wprowadzenie, [w:] eadem, Prawo socjalne, Warszawa 2001, s. 3. 
W tym zakresie należy się odwołać do przepisów Konwencji genewskiej w sprawie traktowania jeńców, a w szczególności art. 4, który definiuje stronę podmiotową oraz prezentuje istotne rozróżnienie na tak zwanych kombatantów i niekombatantów. W szerszym zakresie trzeba też uwzględnić Protokoły dodatkowe przyjęte do Konwencji genewskiej z 1949 roku $^{67}$. Zgodnie z art. 43 ust. 2 Protokołu I do Konwencji genewskiej „Członkowie sił zbrojnych strony konfliktu (inni niż personel medyczny i duchowny objęty artykułem 33 Trzeciej Konwencji) są kombatantami, to jest mają prawo bezpośredniego uczestniczenia w działaniach zbrojnych". Trzeba też zwrócić uwagę na treść art. 44 ust. 3 Protokołu I, który stanowi, że:

Dla wzmocnienia ochrony ludności cywilnej przed skutkami działań wojennych kombatanci są zobowiązani do odróżniania się od ludności cywilnej w czasie, gdy biorą udział w ataku lub w wojskowej operacji przygotowawczej do ataku. Uznając jednak, że w toku konfliktów zbrojnych istnieją sytuacje, gdy wskutek charakteru działań zbrojnych uzbrojony kombatant nie może odróżniać się od ludności cywilnej, zachowuje on swój status kombatanta pod warunkiem, że w takich sytuacjach nosi otwarcie broń.

Prawa do statusu kombatanta lub jeńca wojennego nie ma natomiast najemnik (art. 47 ust. 1 Protokołu I).

$\mathrm{Na}$ gruncie prawa krajowego zdefiniowanie, kto jest kombatantem, stanowi efekt preferencji polityczno-historycznych, dlatego też pojęcie to podlega zmianom. Zasadniczo kombatanctwo stało się terminem ściśle związanym z oceną współczesnej historii przez danego ustawodawcę. Relatywizm tego pojęcia jest szczególnie widoczny w prawie pozytywnym, szczegółowo wyznaczającym krąg osób, którym przysługuje status kombatanta. Znana jest sytuacja, że w określonym ustroju społeczno-politycznym ustawy uznają za kombatantów uczestników konkretnych zdarzeń historycznych relewantnych z punktu widzenia obowiązujących założeń aksjologiczno-ideologicznych, natomiast $\mathrm{w}$ innym ustroju podlegają one rewizji pod kątem nowych aksjomatów ustrojowych. Przykładem takiego działania jest zmiana ustroju politycznego w Polsce po 1989 roku, która spowodowała przewartościowanie dotychczasowych poglądów na to, kto jest osobą zasłużoną. Obowiązująca ustawa o kombatantach nie uznaje już za zasługę udziału w Wielkiej Socjalistycznej Rewolucji Październikowej oraz w wojnie domowej w Hiszpanii w latach 1936-1939. Tytuł kombatanta przestał też przysługiwać osobom, które brały udział w walkach o utrwalenie władzy ludowej w latach $1944-1956^{68}$. Na pewno zagadnienie normatywnych granic przedmiotowych

67 Protokoły dodatkowe do Konwencji genewskich: z 12 sierpnia 1949 roku, dotyczący ochrony ofiar międzynarodowych konfliktów zbrojnych (Protokół I) oraz dotyczący ochrony ofiar niemiędzynarodowych konfliktów zbrojnych (Protokół II), sporządzone w Genewie dnia 8 czerwca 1977 roku, Dz.U. z 1992 r. Nr 41, poz. 175.

68 Po nowelizacji ustawy dokonanej 25 kwietnia 1997 roku części dawnych kombatantów (uczestnikom wojny domowej w Hiszpanii oraz żołnierzom z poboru, którzy pełnili służbę wojskową w Wojsku Polskim w okresie od 10 maja 1945 do 30 czerwca 1947 roku) przywrócono jed- 
pojęcia kombatanta można też rozpatrywać w kategorii instrumentalizacji prawa, jaka miała miejsce w Polsce w okresie transformacji ustrojowej.

Ustawa o kombatantach jest wyrazem uznania i formą rekompensaty dla osób, które w sposób szczególny zasłużyły się w walce o suwerenność i niepodległość Rzeczypospolitej. W myśl art. 1 ust. 1 ustawy:

Kombatantami są osoby, które brały udział w wojnach, działaniach zbrojnych i powstaniach narodowych, wchodząc w skład formacji wojskowych lub organizacji walczących o suwerenność i niepodległość Rzeczypospolitej Polskiej.

Pojęcie działalności kombatanckiej lub równorzędnej z działalnością kombatancką zostało określone również w art. 1 ust. 2 oraz art. 2 ustawy o kombatantach (działalność równorzędna $\mathrm{z}$ kombatancką). Z przytoczonych przepisów jasno wynika, że można mówić o działalności kombatanckiej tylko w kontekście osoby, która aktywnie uczestniczyła w służbie wojskowej lub cywilnej, biorąc udział w wojnach, działaniach zbrojnych i powstaniach narodowych, wchodząc w skład formacji wojskowych lub organizacji walczących o suwerenność i niepodległość Rzeczypospolitej Polskiej.

Zgodnie z art. 21 ust. 1 ustawy o kombatantach uprawnienia kombatanckie przysługują osobie, która uzyska decyzję potwierdzającą działalność wymienioną w art. 1 ust. 2. O potwierdzeniu działalności kombatanckiej orzeka szef Urzędu do Spraw Kombatantów i Osób Represjonowanych ${ }^{69}$ w formie decyzji, na podstawie udokumentowanego wniosku zainteresowanej osoby oraz rekomendacji stowarzyszenia właściwego dla określonego rodzaju działalności kombatanckiej lub represji (art. 22 ust. 1 ustawy).

Pierwotnie w art. 1 ust. 2 ustawy o kombatantach wymieniono enumeratywnie siedem rodzajów działalności w ramach formacji wojskowych, które zostały

nak uprawnienia kombatanckie $\mathrm{W}$ efekcie statusu kombatanta i uprawnień kombatanckich zostały pozbawione tylko osoby, które otrzymały je wyłącznie z tytułu uczestniczenia w walkach o ustanowienie i utrwalenie władzy ludowej. Przepis art. 1 ustawy z dnia 26 maja 1982 roku o szczególnych uprawnieniach kombatantów (Dz.U. z 1982 r. Nr 16, poz. 122) stanowił, że uprawnienia kombatanckie przysługiwały, gdy chodzi o okres po wyzwoleniu kraju spod okupacji hitlerowskiej, „uczestnikom walk o utrwalenie władzy ludowej”. W orzeczeniu z dnia 1 czerwca 1999 roku, $\mathrm{Nr}$ 39860/98 (LEX nr 41096), Europejski Trybunał Praw Człowieka przyjął, że celem ustawy o kombatantach było między innymi potępienie politycznej roli, jaką komunistyczna milicja i służby bezpieczeństwa odgrywały w stworzeniu reżimu komunistycznego i w represjach przeciw opozycji politycznej. Prawodawstwo to oparte jest na założeniu, że członkowie tych służb, których zadaniem było zwalczanie politycznych i zbrojnych organizacji walczących przed 1956 rokiem o niepodległość Polski i odbudowę demokratycznego systemu politycznego, nie zasługują na przywileje, które zostały przyznane im przez ustawę o kombatantach z 1982 roku. Trybunał uznał tym samym, że możliwe jest odebranie przywilejów wynikających z uprawnień kombatanckich bez naruszenia zasad i celu, w jakim ustawa ta została uchwalona.

69 Zgodnie z art. 7 ust. 1 ustawy o kombatantach szef Urzędu do Spraw Kombatantów i Osób Represjonowanych w Warszawie, podległy ministrowi właściwemu do spraw zabezpieczenia społecznego, jest centralnym organem administracji rządowej właściwym w sprawach kombatantów oraz osób, które podlegały represjom wojennym i okresu powojennego. 
zaliczone do działalności kombatanckiej, pośród nich w pkt 6 znalazło się także: „uczestniczenie w walkach w jednostkach Wojska Polskiego oraz zmilitaryzowanych służbach państwowych z oddziałami Ukraińskiej Armii oraz grupami Wehrwolfu".

W latach 1991-1997, w procesie stosowania przepisów ustawy o kombatantach, wyłoniło się jednak istotne zagadnienie prawne, czy udział obywateli polskich w walkach w obronie ludności polskiej w latach 1944-1945 w ramach Istriebitielnych Batalionów na obszarach dawnych województw lwowskiego, wołyńskiego, tarnopolskiego i stanisławowskiego może być uznany za działalność kombatancką. Szczególnie dyskusyjna, z punktu widzenia przesłanek ustawowych, była kwestia prowadzenia przez Bataliony działań operacyjnych w ramach dowództwa NKWD. Kierownik Urzędu do spraw Kombatantów stał konsekwentnie na stanowisku, że uprawnienia kombatanckie nie przysługują z mocy art. 21 ust. 2 pkt 3 ustawy osobie, która służyła w NKWD albo w innych organach represji ZSRR, działających przeciwko narodowi i państwu polskiemu.

W orzecznictwie Naczelnego Sądu Administracyjnego istniała duża rozbieżność w kwestii stosowania przepisów ustawy o kombatantach w odniesieniu do uczestnictwa $\mathrm{w}$ walkach $\mathrm{w}$ ramach Istriebitielnych Batalionów ${ }^{70}$. Przeważał jednak pogląd, że formacje składające się z polskiej ludności cywilnej działające w formie Istriebitielnych Batalionów, związanych z NKWD, nie było służbą w NKWD, lecz raczej rodzajem służby pomocniczej wojsk NKWD. Uczestnictwo w Istriebitielnych Batalionach nie miało zatem charakteru służby wojskowej. W konsekwencji udziału w IB nie można uznać za równorzędny ze służbą w wojskach NKWD w rozumieniu art. 1 ust. 2 pkt 4 analizowanej ustawy. Ponadto, co najistotniejsze, działalność Istriebitielnych Batalionów nie była skierowana bezpośrednio przeciwko ludności polskiej ${ }^{71}$.

Naczelny Sąd Administracyjny, Ośrodek Zamiejscowy we Wrocławiu postanowieniem z dnia 13 października 1995 roku (sygn. SA/Wr 1440-1441/95, niepubl.) zwrócił się do Sądu Najwyższego o udzielenie odpowiedzi na zagadnienie prawne, czy udział obywateli polskich w walkach w obronie ludności polskiej w latach 1944-1945 w ramach Istriebitielnych Batalionów na obszarach dawnych województw lwowskiego, wołyńskiego, tarnopolskiego i stanisławowskiego

70 Wystarczy tu przytoczyć wyrok Naczelnego Sądu Administracyjnego w Warszawie z dnia 6 marca 1989 roku, sygn. II SA 907/88 (niepubl.); i wyrok Naczelnego Sądu Administracyjnego, Ośrodek Zamiejscowy w Krakowie z dnia 15 października 1993 roku, sygn. SA/Kr 2473/92 (niepubl.), w których oddalono skargi na decyzje kierownika Urzędu do Spraw Kombatantów i Osób Represjonowanych odmawiające przyznania uprawnień kombatanckich obywatelom polskim z tytułu walki z UPA w ramach Istriebitielnych Batalionów.

71 Por. wyrok Naczelnego Sądu Administracyjnego, Ośrodek Zamiejscowy we Wrocławiu z dnia 20 czerwca 1994 roku, sygn. SA/Wr 284/94, CBOSA; i wyrok Naczelnego Sądu Administracyjnego, Ośrodek Zamiejscowy w Poznaniu z dnia 9 lutego 1996 roku, sygn. SA/Po 1597/95 (niepubl.). 
może zostać uznany za działalność kombatancką w rozumieniu art. 1 ust. 2 pkt 4 lub 6 ustawy o kombatantach. W razie odpowiedzi negatywnej domagał się udzielenia informacji, czy służba w IB, podjęta i wykonywana w celu obrony ludności polskiej na określonych obszarach, uzasadnia odmowę przyznania uprawnień kombatanckich osobie, która wcześniej pełniła służbę w Armii Krajowej.

Zdaniem NSA na tle definicji działalności kombatanckiej nie można wykluczyć poglądu, że udział w ukraińsko-polskim konflikcie zbrojnym na dawnych obszarach południowo-wschodniej Polski nie został w ogóle objęty dyspozycją art. 1 ust. 1 i 2 ustawy o kombatantach ${ }^{72}$.

W uchwale składu pięciu sędziów z dnia 3 kwietnia 1996 roku (sygn. III AZP 37/97) ${ }^{73}$ Sąd Najwyższy, udzielając odpowiedzi na przedstawione zagadnienie prawne, stwierdził, że udział obywateli polskich w Istriebitielnych Batalionach w latach 1944-1945 nie jest równoznaczny z pełnieniem służby wojskowej w formacjach NKWD w rozumieniu art. 1 ust. 2 pkt 4 ustawy o kombatantach. Zdaniem SN uznanie za działalność kombatancką udziału obywateli polskich w działaniach zbrojnych w formacjach wchodzących w skład struktur należących do NKWD nie jest $\mathrm{w}$ zasadzie $\mathrm{w}$ obecnym stanie prawnym możliwe do przyjęcia mimo istnienia samodzielnej podstawy do uznania uczestnictwa w walkach z oddziałami UPA za działalność kombatancką w rozumieniu art. 1 ust. 2 pkt 6 ustawy.

Podjęcie walki obronnej w stanie wyższej konieczności było w okresie wojny możliwe na terenach dawnych województw południowo-wschodnich Polski po usunięciu Niemców przez Armię Czerwoną w formach organizacyjno-prawnych dopuszczonych i nadzorowanych przez władze ZSRR. Polskie oddziały samoobrony mogły działać po otrzymaniu pozwolenia na posiadanie broni przez władze radzieckie. SN zwrócił jednak uwagę, że na obszarach dawnych województw południowo-wschodniej Polski nie są znane wypadki prowadzenia przez Istriebitielne Bataliony działalności przeciwko ludności polskiej: „Wręcz przeciwnie, stanowiły one jedyną legalną formę organizacyjną w latach 1944 i 1945, stwarzającą możliwość obrony i ocalenia własnego życia, rodziny, sąsiadów oraz okolicznej ludności polskiej przed jej zagładą, powodowaną przez bojówki UPA".

W uchwale Sąd Najwyższy uznał także, że przepis art. 21 ust. 2 pkt 3 ustawy o kombatantach nie uzasadnia odmowy przyznania obywatelowi polskiemu uprawnień kombatanckich z tytułu pełnienia służby w Armii Krajowej, który po rozwiązaniu oddziału na polecenie władz lub rozkaz dowództwa sił zbrojnych

${ }^{72} \mathrm{~W}$ uzasadnieniu postanowienia Naczelny Sąd Administracyjny powołał się na zebrane w sprawie dokumenty, publikacje, oświadczenia i materiały, w tym pismo Światowego Związku Żołnierzy Armii Krajowej Okręgu Lwowskiego w Krakowie z dnia 28 kwietnia 1985 roku, memoriał Stowarzyszenia Upamiętnienia Ofiar Zbrodni Ukraińskich Nacjonalistów we Wrocławiu z dnia 15 grudnia 1994 roku, oświadczenia Środowiska Byłych Żołnierzy Istriebitielnych Batalionów z województw: lwowskiego, stanisławowskiego, tarnopolskiego i wołyńskiego oraz artykuły prasowe prof. E. Prusa, dra J. Wilczura i dra A. Kormana.

73 OSNAPU 1996, nr 20, poz. 295. 
Podziemnego Państwa Polskiego brał udział w walkach z UPA wyłącznie w celu obrony koniecznej ludności polskiej na terenach dawnych województw lwowskiego, stanisławowskiego, tarnopolskiego i wołyńskiego w latach 1944-1945 w ramach Istriebitielnych Batalionów. Uprawnienia kombatanckie mogą być przyznane tym obywatelom polskim, jeżeli będą ustalone w sprawie przez właściwy organ przesłanki faktyczne i prawne określone w art. 1 ust. 2 pkt 3 ustawy o kombatantach.

Sąd Najwyższy doszedł do przekonania, że regulacja zawarta w art. 1 ust. 2 pkt 4 i art. 21 ust. 2 pkt 3 ustawy o kombatantach nie odnosi się do działalności kombatanckiej obywateli polskich biorących udział w walkach w obronie ludności polskiej na obszarach dawnych województw lwowskiego, stanisławowskiego, tarnopolskiego i wołyńskiego, działających w ramach IB. W ocenie SN ustawa o kombatantach nie reguluje tego problemu z powodu braku w art. 1 ust. 2 pkt 4 ustawy dyspozycji wyłączającej ze struktur NKWD formacji Istriebitielnych Batalionów z wymienionych województw dawnych obszarów południowo-wschodniej Polski:

Brak regulacji ustawowej tego problemu uniemożliwia także Sądowi Najwyższemu udzielenie pozytywnej odpowiedzi generalnej na pierwsze pytanie zawarte w przedstawionym do rozstrzygnięcia zagadnieniu prawnym. Usunięcie tego braku wymaga interwencji legislacyjnej ustawodawcy ze względu na wyrażoną w art. 1 Konstytucji Rzeczypospolitej Polskiej zasadę urzeczywistniania sprawiedliwości społecznej w demokratycznym państwie prawnym.

Analizowana materia stała się przedmiotem ingerencji ustawodawcy. $\mathrm{Na}$ mocy art. 1 ustawy z dnia 25 kwietnia 1997 roku o zmianie ustawy o kombatantach oraz niektórych osobach będących ofiarami represji wojennych i okresu powojennego ${ }^{74}$ przepis art. 1 ust. 2 pkt 6 otrzymał brzmienie, zgodnie z którym za działalność kombatancką uznaje się: „uczestniczenie w walkach w jednostkach Wojska Polskiego oraz zmilitaryzowanych służbach państwowych z oddziałami Ukraińskiej Powstańczej Armii oraz grupami Werwolfu". Po pkt 6 dodano pkt 7 w brzmieniu: „uczestniczenie w tzw. Niszczycielskich Batalionach (»Istriebitielnych Batalionach «) na dawnych ziemiach polskich w województwach: lwowskim, stanisławowskim, tarnopolskim i wołyńskim w obronie ludności polskiej przed ukraińskimi nacjonalistami, w latach 1944-1945”. W świetle przyjętej regulacji art. 1 ust. 2 pkt 7 ustawy o kombatantach polscy żołnierze IB otrzymali status kombatantów po spełnieniu jednocześnie trzech warunków, a mianowicie:

1. wchodzili w skład Istriebitielnych Batalionów działających w chociażby jednym z czterech byłych polskich województw południowo-wschodnich: lwowskim, stanisławowskim, tarnopolskim lub wołyńskim;

2. walczyli w obronie ludności polskiej przed nacjonalistami ukraińskimi;

3. walki te trwały w latach 1944-1945.

Po spełnieniu tych warunków żołnierze Batalionów ex lege weszli w skład Korpusu Weteranów Walk o Niepodległość Rzeczypospolitej Polskiej (art. $6^{2}$ ust. 2 ustawy).

74 Dz.U. z 1997 r. Nr 68, poz. 436. 
Uzasadniając wprowadzenie zmian, w imieniu Komisji Polityki Społecznej oraz Komisji Ustawodawczej poseł sprawozdawca Józef Grabek wskazał, że:

Komisja opiera się tutaj na opiniach i stanowiskach: głównie Światowego Związku Żołnierzy Armii Krajowej, Głównej Komisji Badania Zbrodni przeciwko Narodowi Polskiemu, wyrokach Naczelnego Sądu Administracyjnego i uchwale Sądu Najwyższego. Według tych opinii i stanowisk oddziały o nazwie Istriebitielne Bataliony tworzone były z grup samoobrony objętych pieczą i pomocą Armii Krajowej, a w czasie akcji „Burza” wręcz wcielonych do Armii Krajowej. Udział w batalionach, połączony z częściową legalizacją, dawał jedyną możliwość walki zbrojnej z Ukraińską Powstańczą Armią bez narażania się na represje ze strony władz radzieckich za nielegalne posiadanie broni. Stowarzyszenie Upamiętniania Ofiar Zbrodni Ukraińskich Nacjonalistów fakt walki w ramach wymienionych batalionów nazywa stanem wyższej konieczności, wynikającym z ówczesnej sytuacji wojennej. Ograniczenie przepisu tylko do czterech województw wynika z faktu, iż w północnych częściach polskich kresów wschodnich działały formacje o tej samej nazwie, Istriebitielne Bataliony, pod dowództwem NKWD, o innym składzie narodowościowym, wykorzystywane, co udowodniono, do walki z żywiołem polskim i ludnością cywilną. Proponowany przepis, ściśle określający czas, miejsce i charakter walki, winien eliminować dotychczasowe nieporozumienia i spory ${ }^{75}$.

Uczestniczenie w Istriebitielnych Batalionach na dawnych ziemiach polskich w województwach lwowskim, stanisławowskim, tarnopolskim i wołyńskim w obronie ludności polskiej przed ukraińskimi nacjonalistami w latach 1944-1945 zostało uznane przez ustawodawcę za działalność kombatancką. Należy przy tym zwrócić uwagę, że ustawa o kombatantach używa różnych pojęć wskazujących na rodzaj i intensywność żądanej i oczekiwanej od wnioskodawców aktywności stanowiącej podstawę przyznania im uprawnień kombatanckich. Przykładowo tylko należy wskazać, że podstawą przyznania tych uprawnień może być „pełnienie służby wojskowej” (art. 1 ust. 2 pkt 1, 4), ,pełnienie służby” w innych formacjach (art. 1 ust. 2 pkt 3, 5), ,uczestniczenie” w walkach, działaniach, strukturach (art. 1 ust. 2 pkt 6,7). Podstawę taką może stanowić także ,udział” lub „czynny udział” w określonych działaniach (na przykład art. 2 pkt 2 i 6 ).

Przepis art. 1 ust. 2 pkt 7 ustawy uznaje za działalność kombatancką „,uczestniczenie" w Istriebitielnych Batalionach, ale ustawa nie zawiera legalnej definicji tego pojęcia. W tej sytuacji, zgodnie z jedną z dyrektyw wykładni językowej zakazującej przypisywania bez dostatecznych powodów zwrotom interpretowanym swoistego znaczenia prawnego, domniemanie przemawia za potocznym znaczeniem tego pojęcia. Jednocześnie jednak inna z dyrektyw wykładni językowej zakłada, że w języku prawnym nie ma synonimów; jeżeli ustawa nie zawiera rozróżnienia, nie jest zasadne czynienie tego przez interpretatora (lege non distinguente nec nostrum est distinguere). Dlatego nie jest dopuszczalna interpretacja, w myśl której za przesłanką działalności kombatanckiej związanej z Istriebitielnymi Batalionami uznaje się ,pełnienie służby”, a nie, jak stanowi art. 1 ust. 2 pkt 7 ustawy, ,uczestniczenie” w tychże Batalionach. Oznacza to, że organ

75 Druga kadencja Sejmu RP, 105 posiedzenie w dniu 23 kwietnia 1997 roku, http://orka2. sejm.gov.p1/Debata2.nsf/main/5C35A096 (dostęp: 21.01.2021). 
stosujący unormowanie art. 1 ust. 2 pkt 7 ustawy o kombatantach w każdym przypadku powinien, mając na uwadze przedstawione dyrektywy wykładni, rozważyć znaczenie i treść zwrotu „uczestniczenie” w IB, a następnie dokonać subsumcji stanu faktycznego sprawy pod treść tak ustalonej normy prawnej i określić konsekwencje prawne faktu uznanego za udowodniony na podstawie stosowanej normy prawnej ${ }^{76}$.

Zgodnie z dyspozycją przepisu art. 21 ust. 1 ustawy o kombatantach źródłem uprawnień kombatanckich jest między innymi działalność kombatancka określona $\mathrm{w}$ art. 1 ust. 2. O spełnieniu warunków, o których mowa w art. 21 ustawy o kombatantach, zgodnie z dyspozycją art. 22 ustawy orzeka kierownik Urzędu do Spraw Kombatantów i Osób Represjonowanych na podstawie udokumentowanego wniosku zainteresowanej osoby oraz rekomendacji stowarzyszenia właściwego dla określonego rodzaju represji. Brzmienie tych przepisów uprawnia do przyjęcia, że to osoba występująca z wnioskiem o przyznanie uprawnień kombatanckich wskazuje na okoliczności, które stanowią podstawę takiego żądania.

Obowiązek wykazania przesłanek uzasadniających przyznanie uprawnień kombatanckich zasadniczo spoczywa na osobie zainteresowanej, jednakże nie zwalnia to organu od obowiązku podjęcia wszelkich kroków niezbędnych do wyjaśnienia stanu faktycznego. Organ ma obowiązek zebrania całego materiału dowodowego i oceny tego materiału. Aktywność dowodowa organu jest szczególnie wymagana w procesie weryfikacji wniosku o nadanie uprawnień kombatanckich $\mathrm{z}$ tytułu uczestnictwa $\mathrm{w}$ Istriebitielnych Batalionach na dawnych ziemiach polskich w województwach lwowskim, stanisławowskim, tarnopolskim i wołyńskim w obronie ludności polskiej przed ukraińskimi nacjonalistami w latach 1944-1945, ponieważ członkom Batalionów z reguły nie wystawiano zaświadczeń o odbytej służbie ${ }^{77}$. Jest to zatem złożone zagadnienie faktyczno-prawne, w związku z czym musi być rozważone na podstawie wszechstronnie zbadanych i ustalonych faktów.

\section{Bibliografia}

\section{Akty prawne, wyroki i orzeczenia}

105 posiedzenie Sejmu RP w dniu 23 kwietnia 1997 roku, http://orka2.sejm.gov.pl/Debata2.nsf/ main/5C35A096.

Orzeczenie Europejskiego Trybunał Praw Człowieka z dnia 1 czerwca 1999 roku, Nr 39860/98, LEX nr 41096.

76 Zob. wyrok Wojewódzkiego Sądu Administracyjnego we Wrocławiu z dnia 18 lutego 2004 roku, sygn. II SA/Wr 145/01, LEX nr 969400.

77 Zob. wyroki Wojewódzkiego Sądu Administracyjnego we Wrocławiu: z dnia 18 lutego 2004 roku, sygn. II SA/Wr 237/01, CBOSA; i z dnia 9 lutego 2005 roku, sygn. II SA/Wr 501/04, CBOSA. 
Protokoły dodatkowe do Konwencji genewskich: z 12 sierpnia 1949 roku, dotyczący ochrony ofiar międzynarodowych konfliktów zbrojnych (Protokół I) oraz dotyczący ochrony ofiar niemiędzynarodowych konfliktów zbrojnych (Protokół II), sporządzone w Genewie dnia 8 czerwca 1977 roku, Dz.U. z 1992 r. Nr 41, poz. 175.

Uchwała składu pięciu sędziów z dnia 3 kwietnia 1996 roku, sygn. III AZP 37/97, OSNAPU 1996, nr 20, poz. 295.

Ustawa z dnia 26 maja 1982 roku o szczególnych uprawnieniach kombatantów, Dz.U. z 1982 r. $\mathrm{Nr} 16$, poz. 122.

Ustawa z dnia 24 stycznia 1991 roku o kombatantach oraz niektórych osobach będących ofiarami represji wojennych i okresu powojennego, tekst jedn. Dz.U. z 2020 r. poz. 517.

Ustawa z dnia 25 kwietnia 1997 roku o zmianie ustawy o kombatantach oraz niektórych osobach będących ofiarami represji wojennych i okresu powojennego, Dz.U. z 1997 r. Nr 68, poz. 436.

Wyrok NSA, Ośrodek Zamiejscowy w Krakowie z dnia 15 października 1993 roku, sygn. SA/Kr 2473/92 (niepubl.).

Wyroku NSA, Ośrodek Zamiejscowy w Poznaniu z dnia 9 lutego 1996 roku, sygn. SA/Po 1597/95 (niepubl.).

Wyrok NSA, Ośrodek Zamiejscowy we Wrocławiu z dnia 20 czerwca 1994 roku, sygn. SA/Wr 284/94, CBOSA.

Wyrok NSA w Warszawie z dnia 6 marca 1989 roku, sygn. II SA 907/88.

Wyrok WSA we Wrocławiu z dnia 18 lutego 2004 roku, sygn. II SA/Wr 145/01, LEX nr 969400.

Wyrok WSA we Wrocławiu z dnia 18 lutego 2004 roku, sygn. II SA/Wr 237/01, CBOSA.

Wyrok WSA we Wrocławiu z dnia 9 lutego 2005 roku, sygn. II SA/Wr 501/04, CBOSA.

Wyrok Trybunału Konstytucyjnego z dnia 23 września 1997 roku, sygn. K 25/96, OTK 1997, nr 3-4, poz. 36.

Wyrok Trybunału Konstytucyjnego z dnia 15 kwietnia 2003 roku, sygn. SK 4/02, OTK ZU 2003, nr 4, poz. 31 .

Wyrok Trybunału Konstytucyjnego z dnia 9 marca 2004 roku, sygn. K 12/02, OTK ZU 2004, seria A, nr 3, poz. 19.

Wyrok Trybunału Konstytucyjnego z dnia 19 grudnia 2012 roku, sygn. K 9/12, OTK-A 2012, nr 11, poz. 136.

\section{Literatura}

Adamski Ł., Sowieckie relacje o rzezi wotyńskiej, [w:] Sowieci a polskie podziemie 1943-1946. Wybrane aspekty stalinowskiej polityki represji, red. Ł. Adamski, G. Hryciuk, G. Motyka, Warszawa 2017 [e-book].

Balbus T., Polskie „Istriebitielne bataliony” NKWD w latach 1944-1945, „Biuletyn Instytutu Pamięci Narodowej” 2002, nr 6.

Complak K., Komentarz do art. 19 Konstytucji, [w:] Konstytucja Rzeczypospolitej Polskiej. Komentarz, red. M. Haczkowska, Warszawa 2014.

Człowiekowska J., Prawo do sądu jako publiczne prawo podmiotowe, „Zeszyty Naukowe Uniwersytetu Jagiellońskiego" 2006, nr 5.

Filar W., Dziatania UPA przeciwko Polakom na Wotyniu $i$ w Galicji Wschodniej w latach 1943 1944. Podobieństwa i różnice, [w:] Antypolska akcja OUN-UPA 1943-1944. Fakty i interpretacje, red. G. Motyka, D. Libionka, Warszawa 2002.

Filar W., Wotyń 1939-1944. Eksterminacja czy walki polsko-ukraińskie. Studium historyczno-wojskowe zmagań na Wotyniu w obronie polskości, wiary i godności ludzkiej, Toruń 2003.

Florczak-Wątor M., Horyzontalny wymiar praw konstytucyjnych, Kraków 2014.

Garlicki L., Polskie prawo konstytucyjne. Zarys wykładu, Warszawa 2020.

Studia nad Autorytaryzmem i Totalitaryzmem 42, nr 4, 2020

(C) for this edition by CNS 
Garlicki L., Derlatka M., Komentarz do art. 19 Konstytucji, [w:] Konstytucja Rzeczypospolitej Polskiej. Komentarz, red. L. Garlicki, M. Zubik, t. 1, Warszawa 2016.

Hryciuk G., Akcje UPA przeciwko Polakom po ponownym zajęciu Wolynia i Galicji Wschodniej przez Armię Czerwona w 1944 roku, [w:] Antypolska akcja OUN-UPA 1943-1944. Fakty i interpretacje, red. G. Motyka, D. Libionka, Warszawa 2002.

Hryciuk G., Przemiany narodowościowe i ludnościowe w Galicji Wschodniej i na Wotyniu w latach 1931-1948, Toruń 2005.

Iljuszyn I., Sowieckie represje wobec ludności ukraińskiej i polskiej na zachodnim Wołyniu I Galicji Wschodniej (w latach 1944-1946), [w:] Sowieci a polskie podziemie 1943-1946. Wybrane aspekty stalinowskiej polityki represji, red. Ł. Adamski, G. Hryciuk, G. Motyka, Warszawa 2017 [e-book].

Jabłoński M., Prawo weteranów do specjalnej opieki ze strony państwa, [w:] Realizacja i ochrona konstytucyjnych wolności i praw jednostki w polskim porzadku prawnym, red. M. Jabłoński, Wrocław 2014.

Jakimowicz W., Publiczne prawa podmiotowe, Warszawa 2002.

Jaskiernia J., Funkcje Konstytucji RP $w$ dobie integracji europejskiej i radykalnych przemian politycznych, Toruń 2020.

Jastrzębski S., Kresy wschodnie we krwi. Rzecz o polskiej samoobronie, Wrocław 2001.

Jastrzębski S., Ludobójstwo ludności polskiej przez OUN-UPA w województwie stanisławowskim w latach 1939-1946, Warszawa 2004.

Jastrzębski S., Ocalić od zapomnienia. Eksterminacja Polaków na Kresach Południowo-Wschodnich $i$ Wotyniu w latach 1939-1946, Katowice 2016.

Jastrzębski S., Oko w oko z banderowcami, Wrocław 2010.

Jędrasik-Jankowska I., Ustawa o kombatantach oraz niektórych osobach będących ofiarami represji wojennych i okresu powojennego. Wprowadzenie, [w: ] eadem, Prawo socjalne, Warszawa 2001.

Juszkiewicz J., Adwokat Rafat Lemkin - twórca koncepcji prawnej zbrodni ludobójstwa, „Żydzi Wschodniej Polski”, seria 4. Uczeni żydowscy, red. G. Czerwiński, J. Ławski, Białystok 2016.

Komański H., Siekierka S., Ludobójstwo dokonane przez nacjonalistów ukraińskich na Polakach w województwie tarnopolskim 1939-1946, Wrocław 2004.

Kordela M., Zasady prawa. Studium teoretycznoprawne, Poznań 2012.

Kuźniar B., Dowody zbrodni nacjonalistów ukraińskich na ludności polskiej w latach 1939-1947 oraz ich ocena w świetle prawa krajowego i międzynarodowego, „Przegląd Geopolityczny” 2015, nr 12.

Ławniczak A., Masternak-Kubiak M., Republikańska forma państwa w ujęciu Konstytucji RP, „Państwo i Prawo" 1999, nr 8.

Łętowska E., Uwagi o weryfikacji kombatantów, [w:] Prawo pracy a wyzwania XXI wieku, kom. red. M. Matey-Tyrowicz, L. Nawacki, B. Wagner, Warszawa 2002.

Motyka G., Od rzezi wotyńskiej do akcji ,, Wisła”. Konflikt polsko-ukraiński 1943-1947, Kraków 2011.

Motyka G., Ukrainska partyzantka 1942-1960. Działalność Organizacji Ukraińskich Nacjonalistów i Ukraińskiej Powstańczej Armii, Warszawa 2015.

Motyka G., Wotyń '43, Kraków 2016.

Musiał B., Sowieccy partyzanci 1941-1944. Mity i rzeczywistość, przeł. z jęz. niem. E. Stefańska, Poznań 2014.

Rutkiewicz J., Kulikow W.N., Wojska NKWD 1917-46, Warszawa 1998.

Semczyszyn M., Nikita Chruszczow wobec Polaków i polskiego podziemia na Wotyniu i w Galicji Wschodniej w latach 1943-1945, [w:] Sowieci a polskie podziemie 1943-1946. Wybrane aspekty stalinowskiej polityki represji, red. Ł. Adamski, G. Hryciuk, G. Motyka, Warszawa 2017 [e-book].

Serczyk W.A., Historia Ukrainy, Wrocław 1990.

Studia nad Autorytaryzmem i Totalitaryzmem 42, nr 4, 2020

(C) for this edition by CNS 
Siekierka S., Komański H., Różański E., Ludobójstwo dokonane przez nacjonalistów ukraińskich na Polakach w województwie stanistawowskim 1939-1946, Wrocław 2007.

Siemaszko E., Bilans zbrodni, „Biuletyn Instytutu Pamięci Narodowej” 2010, nr 7-8.

Siemaszko E., Genocidium atrox, „Do Rzeczy. Historia” 5, 2013.

Siemaszko E., Ludobójcze akcje OUN-UPA w lipcu 1943 roku na Wolyniu, [w:] Antypolska akcja OUN-UPA 1943-1944. Fakty i interpretacje, red. G. Motyka, D. Libionka, Warszawa 2002.

Siemaszko W., Siemaszko E., Ludobójstwo dokonane przez nacjonalistów ukraińskich na ludności polskiej Wotynia 1939-1945, t. 1-2, Warszawa 2000.

Spychalska A., Rafat Lemkin - twórca pojęcia „,ludobójstwo”, [w:] Acta Erasmiana, t. 2. Prace z myśli polityczno-prawnej oraz prawa publicznego, red. M. Sadowski, P. Szymaniec, Wrocław 2012.

Stryjek T., Europejskość Dymytra Doncowa, czyli o cechach szczególnych ideologii ukraińskiego nacjonalizmu, [w:] Antypolska akcja OUN-UPA 1943-1944. Fakty i interpretacje, red. G. Motyka, D. Libionka, Warszawa 2002.

Szawłowski R., Rafat Lemkin — twórca pojęcia ,, ludobójstwo” i główny architekt Konwencji z 9 XII 1949 (w czterdziesta rocznicę śmierci), „Państwo i Prawo” 1999, nr 10.

Ujazdowski K.M., Tożsamość i funkcjonowanie Konstytucji Rzeczypospolitej Polskiej z 2 kwietnia 1997 roku, „Prawo i Więź” 2014, nr 2.

Zajączkowski M., Stosunki polsko-sowieckie na Wotyniu w świetle dokumentów czerwonych partyzantów, [w:] Sowieci a polskie podziemie 1943-1946. Wybrane aspekty stalinowskiej polityki represji, red. Ł. Adamski, G. Hryciuk, G. Motyka, Warszawa 2017 [e-book].

Ziembicki S., Kilka uwag o Rafale Lemkinie - twórcy pojęcia ,genocyd”, [w:] Wybitni prawnicy na przestrzeni wieków, red. M. Marszał, J. Przygodzki, Wrocław 2006.

Zychowicz P., Z wrogiem na wroga, „Rzeczpospolita” 16.01.2010. 